\title{
Structure of the invertebrate fauna in salt marshes of the Wadden Sea coast of Schleswig-Holstein influenced by sheep-grazing*
}

\author{
H. Meyer ${ }^{1}$, H. Fock ${ }^{2}$, A. Haase ${ }^{2}$, H. D. Reinke ${ }^{1}$ \& I. Tulowitzki ${ }^{1}$ \\ ${ }^{1}$ Forschungsstelle für Ökosystemforschung und Ökotechnik, Zoologisches Institut der \\ Universität Kiel; Olshausenstr. 40, D-24118 Kiel, Germany \\ ${ }^{2}$ Forschungs- und Technologiezentrum Westküste, AG Küstenökologie; Hafentörn, \\ D-25761 Büsum, Germany
}

\begin{abstract}
Results of investigations on the influence of five different sheep grazing intensities on the invertebrate fauna of two mainland salt marsh sites of the German Wadden Sea coast are presented for the years 1990 and 1991. The investigation of the invertebrate fauna has been carried out since 1989 in the Puccinellia maritima zone, and the Festuca-Puccinellia as well as the FestucaArmeria zones, with trapping transects arranged along an inundation gradient. Apart from specific biotic effects, grazing causes changes in environmental characteristics. Effects on microclimate comprise higher ranges of variance in soil-surface temperature on grazed sites. Decreasing food resources caused by grazing bring disadvantages to herbivores, the major part of the invertebrate fauna, due to merotope destruction (e.g. inflorescences of Aster tripolium) and the decline of host plant stands (e.g. A. tripolium, Plantago ssp.). Flower visitors and pollen feeding species that depend on A. tripolium have become extinct. Increasing food resources, caused by grazing, lead to higher population densities of a few specialized grass-feeding and surface-grazing invertebrates (e.g. Mayetiola ssp., Psammotettix putoni, Bledius tricornis). Soil characteristics in the lower salt marsh have not been altered significantly by grazing; hence, the direct effect of grazing and trampling leads to a decrease in population density of many species such as Assiminea grayana, Orchestia gammarellus and collembolans. The biomass and abundance of detritivores and many herbivores increased from 1990 to 1991 on the totally grazed fields, whereas predators diminished in numbers at the same time. A descriptive model is presented, involving grazing, winter temperature, and precipitation as basic factors.
\end{abstract}

\section{INTRODUCTION}

The supralittoral area of the Wadden Sea is formed by the salt marshes, a transient zone between the intertidal reaches and the marsh polders. In an undisturbed supralittoral ecosystem, flooding frequency and sedimentation/erosion processes rule the salt marsh succession from the low-lying Spartina- and Salicornia-stages to the high-lying Juncetum gerardii-stage with Festuca rubra litoralis (Andresen et al., 1990; Heydemann, 1981). Human interference superimposes on the landscape's evolution through land reclamation with intensive drainage, recreational activities, and grazing by sheep, geese,

\footnotetext{
- Publication No. 38 of the project Ecosystem Research Wadden Sea
} 
cattle or horses. In Schleswig-Holstein only 7800 ha $(40 \%)$ out of ca 19500 ha of salt marshes comprising the Puccinellia maritima-zone and the Festuca rubra-zone are left. This is due to intensive land reclamation during the last fifty years (Prokosch \& Kempf, 1987; Stock, 1993).

Seventy-percent of the Schleswig-Holstein salt marshes are grazed intensively by sheep (3.4 SE $=9-10$ sheep per ha), another $23 \%$ are kept under reduced grazing conditions, and only a minor part $(7 \%)$ is excluded from any use (Prokosch \& Kempf, 1987). The effects of grazing and trampling by cattle, horses and sheep have already been under critical discussion (Bakker, 1990; Prokosch, 1990). The effects of different intensities of cattle grazing have been studied by Irmler \& Heydemann (1986), Andresen et al. (1990) and Grell (1992). However, sheep grazing is different from cattle grazing. It is this study's aim to evaluate the effects of the five different sheep grazing intensities, and to derive successful management concepts to recover the original ecological value of salt marshes.

This study is part of the project A 5, dealing with salt marshes of the interdisciplinary Ecosystem Research Wadden Sea-venture, carried out in close cooperation with the Botanisches Institut Abt. Vegetationskunde der CAU Kiel and with the Authority for the Wadden Sea National Park.

\section{MATERIALS AND METHODS}

\section{Study areas}

The investigations have been carried out since 1988 at two mainland salt-marsh areas (Fig. 1): Sönke-Nissen-Koog (SNK), ca 70 years old, and Friedrichskoog (FK), ca 150 years old. Each site is managed with five different grazing intensities of 0.0 (ungrazed), 0.5, 1.0 (both moderately grazed), 1.5 (medium grazed), and 3.4 (totally grazed, usual grade) sheep equivalents (SE) per ha (1 $\mathrm{SE}=$ ca 3 sheep). The total investigation area included 55 ha (SNK) and 72 ha (FK).

The SNK area is covered by the Puccinellia maritima-association, interspersed in the ungrazed fields with small patches of Agropyron littoralis and Festuca rubra littoralis. The moderately sloping FK area inhabits a mosaic of several vegetational units comprising the Puccinellia maritima-zone, and the Festuca rubra-Puccinellia maritima as well as the Festuca rubra-Armeria maritima-type of the Juncetum gerardii. Each study area is well ditched. The remaining fields have an area of ca $1000 \mathrm{~m}^{2}$.

\section{Abiotic methods}

Microclimate recordings were carried out by means of a data logger climate station mounted on a $3 \mathrm{~m}$ platform near the dikeline which measured temperature at four vertical levels $-5 \mathrm{~cm}, 0 \mathrm{~cm},+15 \mathrm{~cm}$ and $300 \mathrm{~cm}$ above ground. Soil samples were taken from the $0-4 \mathrm{~cm}$ surface layer with a $25 \mathrm{~cm}^{2}$ corer $\left(100 \mathrm{~cm}^{3}\right)$. Soil samples were dried at $105^{\circ} \mathrm{C}$ for $24 \mathrm{~h}$, and ignition loss (organic matter) was determined at $450^{\circ} \mathrm{C}$ for $15 \mathrm{~h}$. To avoid mistrials caused by remaining roots, each sample was treated with a $630 \mu \mathrm{m}$ mesh-size sieve. Texture analysis was done by wet sieving using a detercent Salinity was measured conductometrically by titration with $\mathrm{AgNO}_{3}$. 


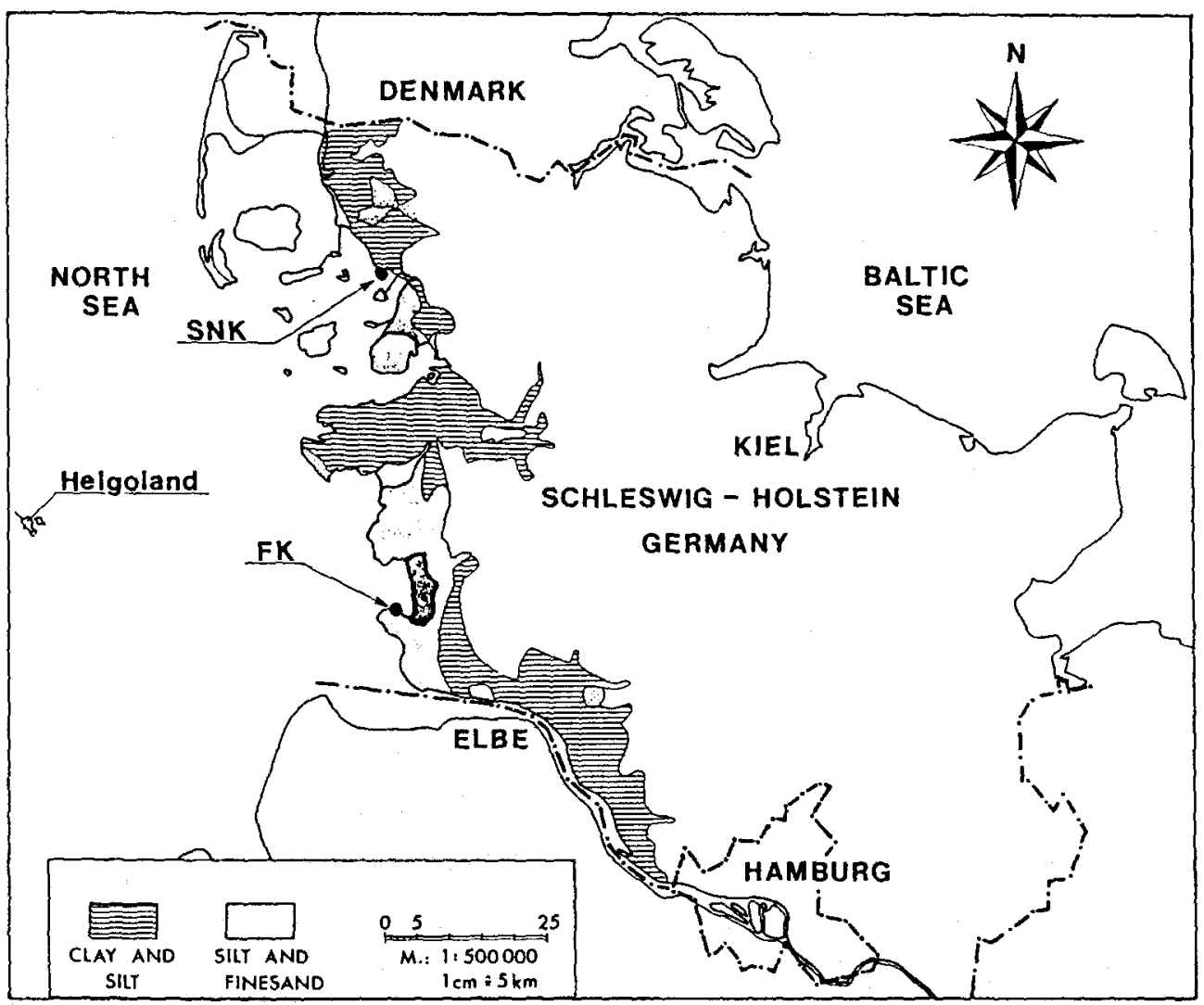

Fig. 1. Map of study areas. Soil texture distribution for the coastal zone (Schott, 1956). Sönke-NissenKoog (SNK) is located in a clay zone, whereas Friedrichskoog (FK) is an area of fine sand

Fauna sampling design and sample treatment

Several methods (Table 1, Fig. 2) were applied to obtain fauna samples (Weigmann, 1973; Heydemann, 1956; Irmler \& Heydemann, 1986). Traps were set and sampling was done along an inundation gradient with five transect points, and a total of 25 sampling sites in each area. Sampling was performed from April to October in both years. Field counts were carried out for flower visitors and inhabitants of Aster tripolium.

Seventy percent ethyl-alcohol was used for final preservation of the samples. Dry weight was obtained after drying of fresh material (herbivorous Coleoptera, Diptera, Rhynchota) or preserved samples (Collembola, Cicadina, Miridae, Gastropoda) according to Southwood (1978) and Brey (1986). For collembolans, ash free dry weight was determined after burning at $450^{\circ} \mathrm{C}$. Length measurements of gastropoda were carried out according to Ziegelmeier (1966) with an ocular micrometer on a dissecting microscope. Production and turnover rates for cicads and plant bugs were derived using the following cohort formula from Winberq et al (1971): 


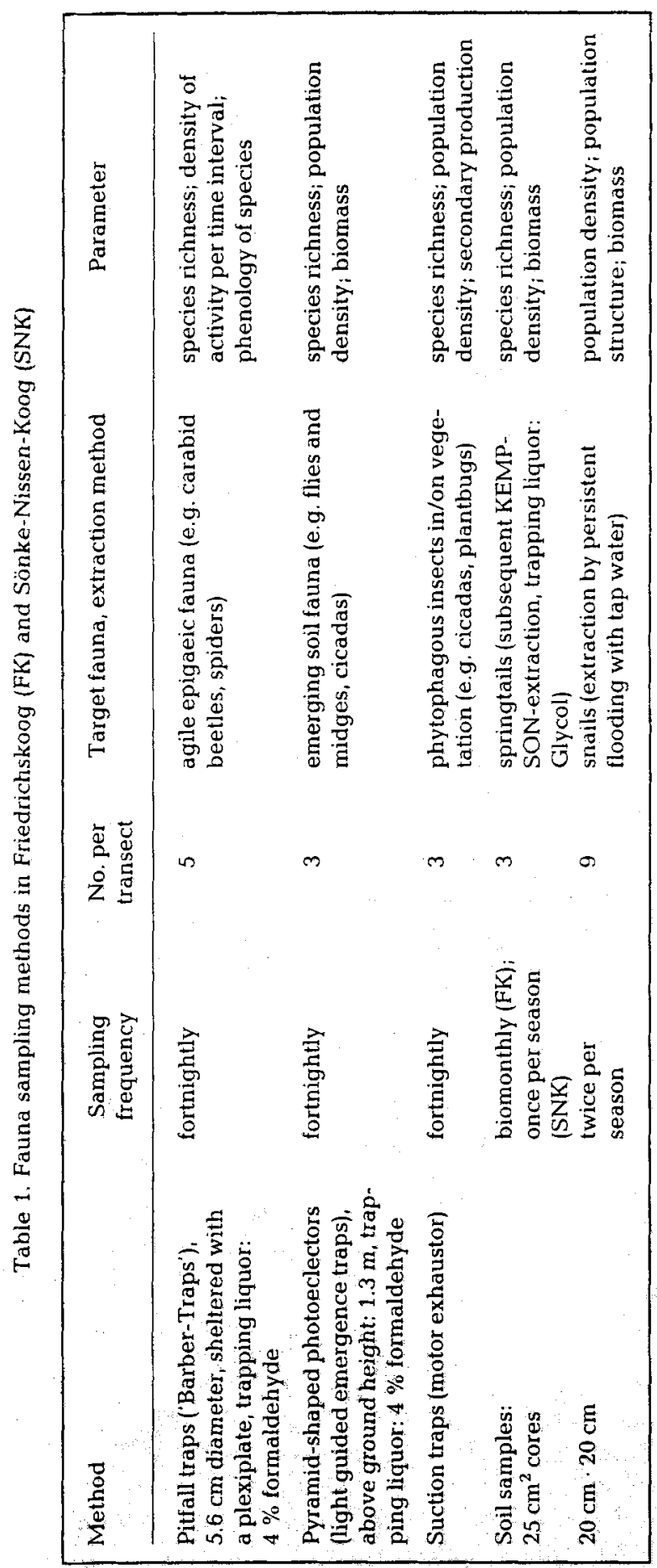



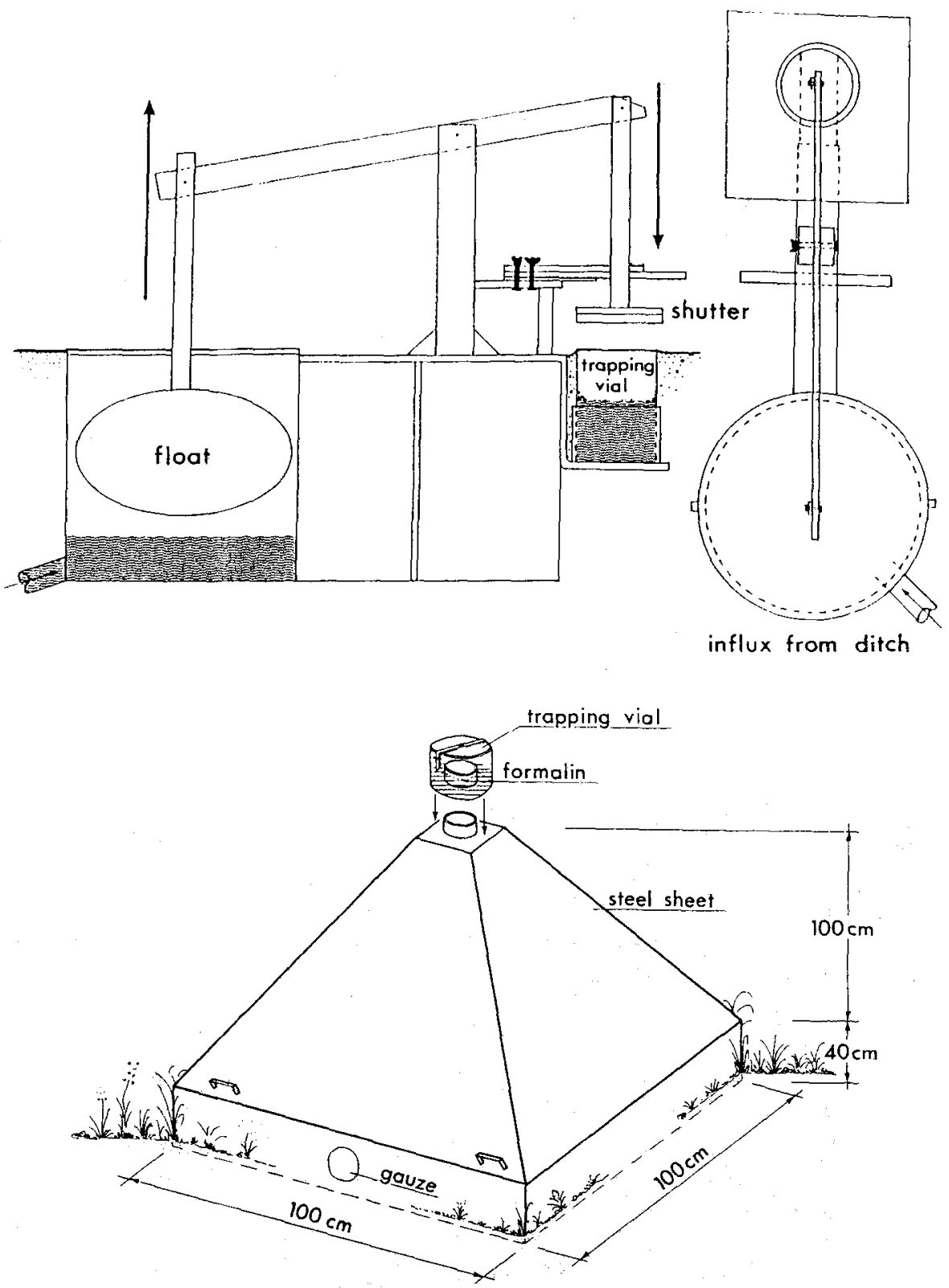

Fig. 2. Model of the pitfall trap (above) and the pyramidal photoeclector (below) used in this study. Vials of both traps changed fortnightly, photoeclectors removed after 30 days 


$$
P_{i}=\frac{N_{i t}+N_{i 0}}{2} \cdot\left(W_{i t}-W_{i 0}\right)
$$

and

$$
P=\sum P_{i}
$$

$\mathrm{N}=$ abundance, $\mathrm{w}=$ average weight, $\mathrm{t}, 0=$ time interval between 0 and $\mathrm{t}, \mathrm{i}=$ cohort number, $\mathrm{P}=$ production

Calculations were based on biomass data from Tulowitzki (1990) for alcohol preserved weight of Psammotettix putoni. Turnover rates were calculated by the quotient, production(P)/biomass(B).

\section{Statistics}

The Renkonen-Index was used to compute similarity (Renkonen, 1938). Unweighted cluster-analysis was carried out according to Sneath \& Sokal (1973).

\section{RESULTS}

\section{Abiotic environment}

Microclimate

Effects of grazing on microclimate depend on three causal principles: reduction of canopy, increased evaporation, and penetration of solar radiation to the ground. The reduction of canopy reduces the isolating effect of vegetation to the environment and enables the wind to attack the soil surface directly. Hence, temperature ranges increase under grazing at the soil surface and in the subsurface layer $(0 \mathrm{~cm} /-5 \mathrm{~cm})$, while the ranges in the vegetation layer $(+15 \mathrm{~cm}$ above ground) show a contrasting trend with a maximum in the ungrazed field (Fig. 3).

\section{Soil characteristics}

The FK sites contain on average a higher amount of fine sand components than the SNK sites. Schott (1956) has already shown that soil at the county's mainland northwestern and southern coast mainly contains high amounts of clay and silt (SNK), interrupted by an area largely consisting of fine sand (FK) (Fig. 1).

The proportion of organic content and of the fine material $(<20 \mu \mathrm{m})$ increased the more sheltered the salt marsh was (Table 2). The Puccinellia maritima-zone in FK was exposed directly to tidal energy (shoreline distance to sampling point ca $50 \mathrm{~m}$ ). Shoreline distance of the sampling point in SNK was about $200 \mathrm{~m}$ and in the Festuca-Armeria-zone in FK about $850 \mathrm{~m}$ (Table 2). Differences between ungrazed and fully grazed sites (3.4 SE) occurred mainly in the higher zones. The amount of organic matter increased slightly; whereas soil salinity increased enormously, with a maximum in the transient FestucaPuccinellia-zone. In contrast, bulk density decreased under grazing pressure (Table 3). There was no clear difference between zero and maximal grazing in any characteristics of the Puccinellia maritima-zone in FK. 

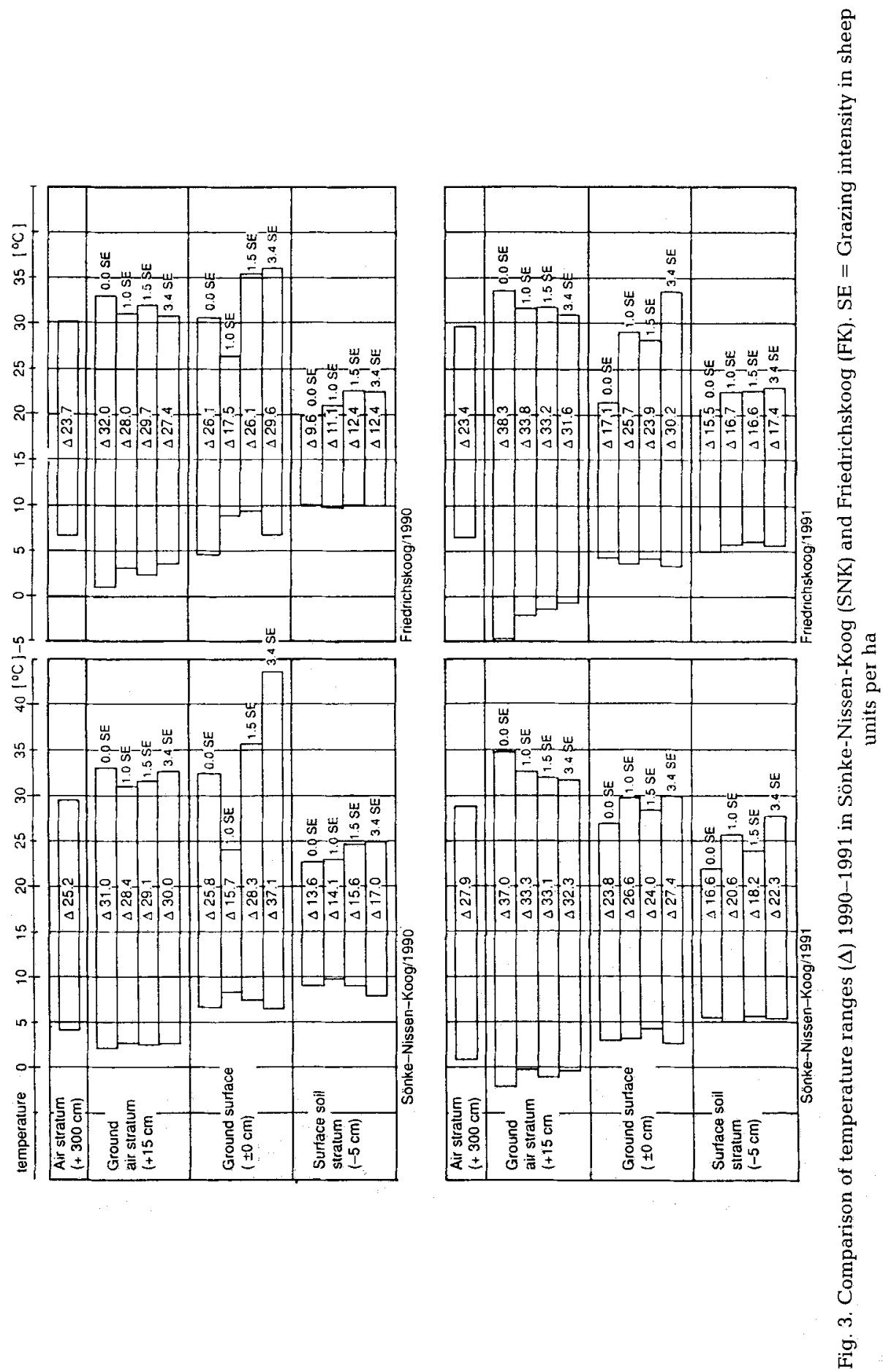
Table 2. Soil properties. Mixed sample out of 2 subsamples in different zones of Friedrichskoog (FK) and Sönke-Nissen-Koog (SNK) 1989-1991

\begin{tabular}{|c|c|c|c|c|c|}
\hline \multirow[t]{2}{*}{ Location } & \multirow[t]{2}{*}{ Zone } & \multirow{2}{*}{$\begin{array}{l}\text { Organic matter } \\
\text { (\% of dry } \\
\text { matter) }\end{array}$} & \multicolumn{3}{|c|}{$\begin{array}{c}\text { Texture } \\
(\% \text { of dry inorganic matter })\end{array}$} \\
\hline & & & $>63 \mu \mathrm{m}$ & $63 \mu \mathrm{m}>\mathrm{x}>20 \mu \mathrm{m}$ & $<20 \mu \mathrm{m}$ \\
\hline \multirow[t]{2}{*}{ SNK } & $\begin{array}{l}\text { Pucc. maritima- } \\
\text { zone } \\
\text { ungrazed }\end{array}$ & 4.4 & 16.6 & 69.4 & 14 \\
\hline & $\begin{array}{l}\text { Pucc. maritima- } \\
\text { zone } \\
\text { fully grazed }\end{array}$ & 6.4 & 21.2 & 66.8 & 12 \\
\hline \multirow[t]{4}{*}{ FK } & $\begin{array}{l}\text { Fest.-Armeria- } \\
\text { zone } \\
\text { ungrazed }\end{array}$ & 11 & 38.7 & 46.9 & 14.4 \\
\hline & $\begin{array}{l}\text { Fest.-Armeria- } \\
\text { zone } \\
\text { fully grazed }\end{array}$ & 15 & 27.5 & 53.7 & 18.8 \\
\hline & $\begin{array}{l}\text { Pucc, maritima- } \\
\text { zone } \\
\text { ungrazed }\end{array}$ & 3.1 & 40.4 & 53.8 & 5.8 \\
\hline & $\begin{array}{l}\text { Pucc. maritima- } \\
\text { zone } \\
\text { fully grazed }\end{array}$ & 3.1 & 42 & 52.5 & 5.5 \\
\hline
\end{tabular}

Table 3. Ecophysiological soil conditions in different zones of Friedrichskoog (FK) 1989-1991 (s.d. = standard deviation)

\begin{tabular}{|c|c|c|c|c|c|c|}
\hline \multirow{2}{*}{$\begin{array}{l}\text { Salt marsh } \\
\text { zonation } \\
\text { of FK } \\
\text { ( } \pm \text { s.d.) }\end{array}$} & \multicolumn{3}{|c|}{$\begin{array}{c}4 \text { years abandoned, since } 1988 \\
\text { data } 1989-1991, \mathrm{n}=13\end{array}$} & \multicolumn{3}{|c|}{$\begin{array}{l}\text { Totally grazed; } 3.4 \mathrm{SE} \\
\text { data } 1989-1991, \mathrm{n}=13\end{array}$} \\
\hline & $\begin{array}{l}\text { Festuca- } \\
\text { Armeria- } \\
\text { zone }\end{array}$ & $\begin{array}{c}\text { Festuca- } \\
\text { Puccinellia- } \\
\text { zone }\end{array}$ & $\begin{array}{c}\text { Puccinellia } \\
\text { maritima- } \\
\text { zone }\end{array}$ & $\begin{array}{c}\text { Festuca- } \\
\text { Armeria- } \\
\text { zone }\end{array}$ & $\begin{array}{c}\text { Festuca- } \\
\text { Puccinellia- } \\
\text { zone }\end{array}$ & $\begin{array}{c}\text { Puccinellia } \\
\text { maritima- } \\
\text { zone }\end{array}$ \\
\hline $\begin{array}{l}\text { Bulk density } \\
{\left[\mathrm{g} / \mathrm{cm}^{3}\right]} \\
0-4 \mathrm{~cm}\end{array}$ & $\begin{array}{l}0.90 \\
(0.064)\end{array}$ & $\begin{array}{l}1.14 \\
(0.113)\end{array}$ & $\frac{1.16}{(0.127)}$ & $\begin{array}{l}0.81 \\
(0.042)\end{array}$ & $\begin{array}{c}0.98 \\
(0.035)\end{array}$ & $\frac{1.16}{(0.050)}$ \\
\hline $\begin{array}{l}\text { Soil salinity } \\
{[\% 0], 0-4 \mathrm{~cm}}\end{array}$ & $\begin{array}{l}10.4 \\
(5.31)\end{array}$ & $\begin{array}{l}13.7 \\
(7.05)\end{array}$ & $\frac{14.4}{(6.25)}$ & $\begin{array}{l}14.0 \\
(4.91)\end{array}$ & $\begin{array}{l}15.2 \\
(4.84)\end{array}$ & $\frac{14.4}{(6.56)}$ \\
\hline
\end{tabular}

\section{Effects on organisms}

\section{Abundance changes of dominant species}

Invertebrate species usually showed a distinct reaction towards grazing. In many cases the trend was interrupted by an abundance peak with moderate grazing intensities (Figs 5,6 , and 7). 


\section{Extinction of flower visitors}

Only a small number of salt marsh plants are entomophiles. Among them is Aster tripolium, which is the most important one. Solely the ungrazed fields represented favourable conditions for the Aster plants to reach flowerage. The nectar and pollen of this food resource was exploited by syrphid flies, hymenopteres, and macrolepidopteres, mainly immigrating from the polders (Fig. 4). The flower itself was inhabited by tephritid flies and microlepidopteres which are indigenous to the salt marsh ecosystem. The tephritid fly, Paroxyna plantaginis, was most abundant in abandoned sites with an average of 62 specimen per 10 flowers (SNK).

\section{Decrease in herbivorous and surface-living species}

The species belonging to this category made up the major part of the biomass and specimen of the salt marsh invertebrate fauna. Herbivorous species utilizing the whole upper or underground corpus of vascular plants, e. g. the curculionid beetles Otiorhyn-

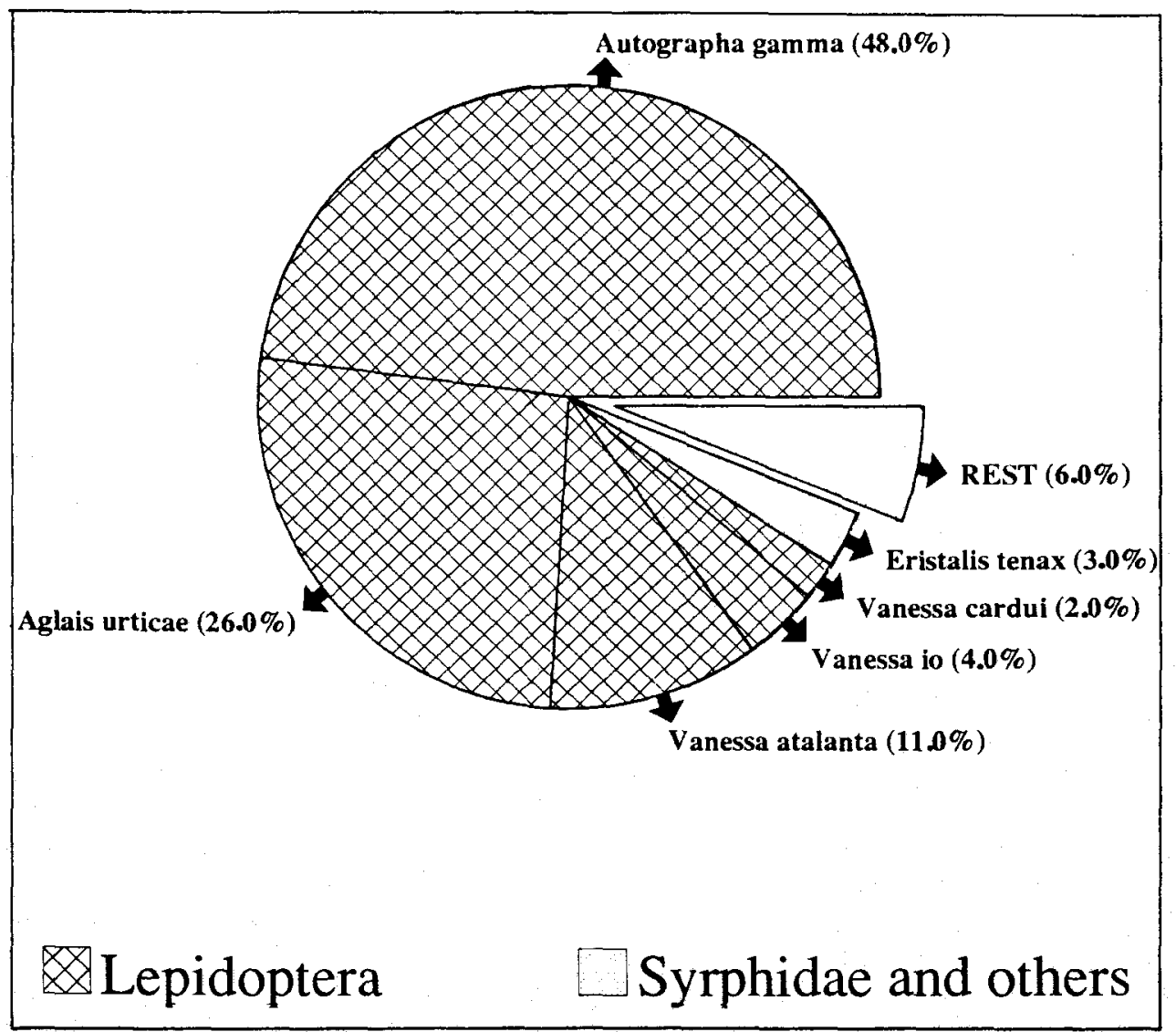

Fig. 4. Average number of flower visitors on Aster tripolium. Sönke-Nissen-Koog (SNK) (30th August 1990 and 30th August 1991) 
chus frisius and Phyllobius verspertinus, were severely damaged by grazing, especially at the 3.4 SE-intensity (Fig. 5). The imago of $P$. vespertinus is polyphagous, but its larvae feed on grassroots of Festuca sp. and Agrostis sp.; whereas $O$. frisius is oligophagous and mainly depends on Plantago-plants at both life stages (Tischler, 1985).

Specialized herb feeding species, such as the plantbug Conostethus frisicus (Fig. 5), decreased with the decline of the host plants, Suaeda maritima and Limonium vulgare (Hildebrandt, 1990), which are both sensitive to grazing (Jensen, 1985). The cicad Anoscopus limicola also reacted sensitively towards grazing, although its host plant, Puccinellia maritima, represents a grass species with enhanced development under grazing conditions. Some herbivorous species feeding on grasses benefit from the reduction of herbs, and the enhanced development of fresh grass shoots due to moderate grazing. These can also get reduced, though, at higher grazing intensities. Examples include the cicad Psammotettix putoni, and the gall midge Mayetiola puccinelliae. It should be taken into consideration, that slight grazing by wild geese occurred in the 0.0 SE fields in FK, so that fresh shoots were provided here, too, creating appropriate living conditions for $P$. putoni and $M$. puccinelliae. This was indicated by the relatively high values in the $0.0 \mathrm{SE}$ sites at FK (Fig. 6). In contrast, the gall midge Mayetiola agrostivora clearly benefits from grazing due to the increased abundance of its host plant Agrostis stolonifera (Meyer, 1984) which, as a small species, has competing advantage under grazing conditions against all tall plants. Surface active species, like the grazing gastropod Assiminea grayana and the detritovorous amphipod Orchestia gammarellus, showed a steady decrease of abundance in the Puccinellia-zone of FK during phases of increasing grazing intensity (Fig. 5). O. gammarellus lives in caverns of the upper soil stratum and prefers surface structures, sheltered by a tomentous layer of decaying plant material, only present on abandoned sites. However, in the higher Festuca-zones of FK, A. grayana shifted from the ungrazed to the moderately grazed areas, but then decreased sharply at higher intensities. In SNK (not depicted) $A$. grayana reached average densities of $880 \mathrm{specimen} / \mathrm{m}^{2}$ (1991). Once again, the 0.5 and the 1.5 -SE sites mounted to relatively high values of $1000 \mathrm{n} / \mathrm{m}^{2}$ and $1100 \mathrm{n} / \mathrm{m}^{2}$, respectively, whereas the 3.4 -SE sites are inhabited by only $650 \mathrm{n} / \mathrm{m}^{2}$. The SNK Puccinellia maritima-zone displayed reactions to grazing similar to those observed in Festuca-zone of FK.

In the FK-Puccinellia maritima-zone, the abundance of collembolans declined constantly, except for a small peak in 1990 in the 1.5 SE site in FK (Fig. 13).

Increase in microphytophages and small detritophages

The population density of microphytophages rose up constantly along with increasing stocking rates. Examples were the staphylinid beetle Bledius tricornis, the weaponfly Nemotelus notatus, and the crane-fly Symplecta stictica (Fig. 7).

Detritophagous collembolans showed similar differences to those already mentioned for A. grayana. The highest densities were reached in 1991 in the higher fields under moderate grazing conditions, and even in the totally grazed Festuca-Armeria-fields, more yield resulted than under zero grazing. In the higher fields Isotoma viridis is the dominant collembolan species with respect to biomass (Fig. 7).

In the more sheltered SNK-Puccinellia-zone, the highest population density of collembolans was demonstrated in 1990 at the 3.4 SE-grazing intensity, with 13200 specimen $/ \mathrm{m}^{2}$, compared to 5200 specimen $/ \mathrm{m}^{2}$ in the ungrazed zone. Actually, these were 

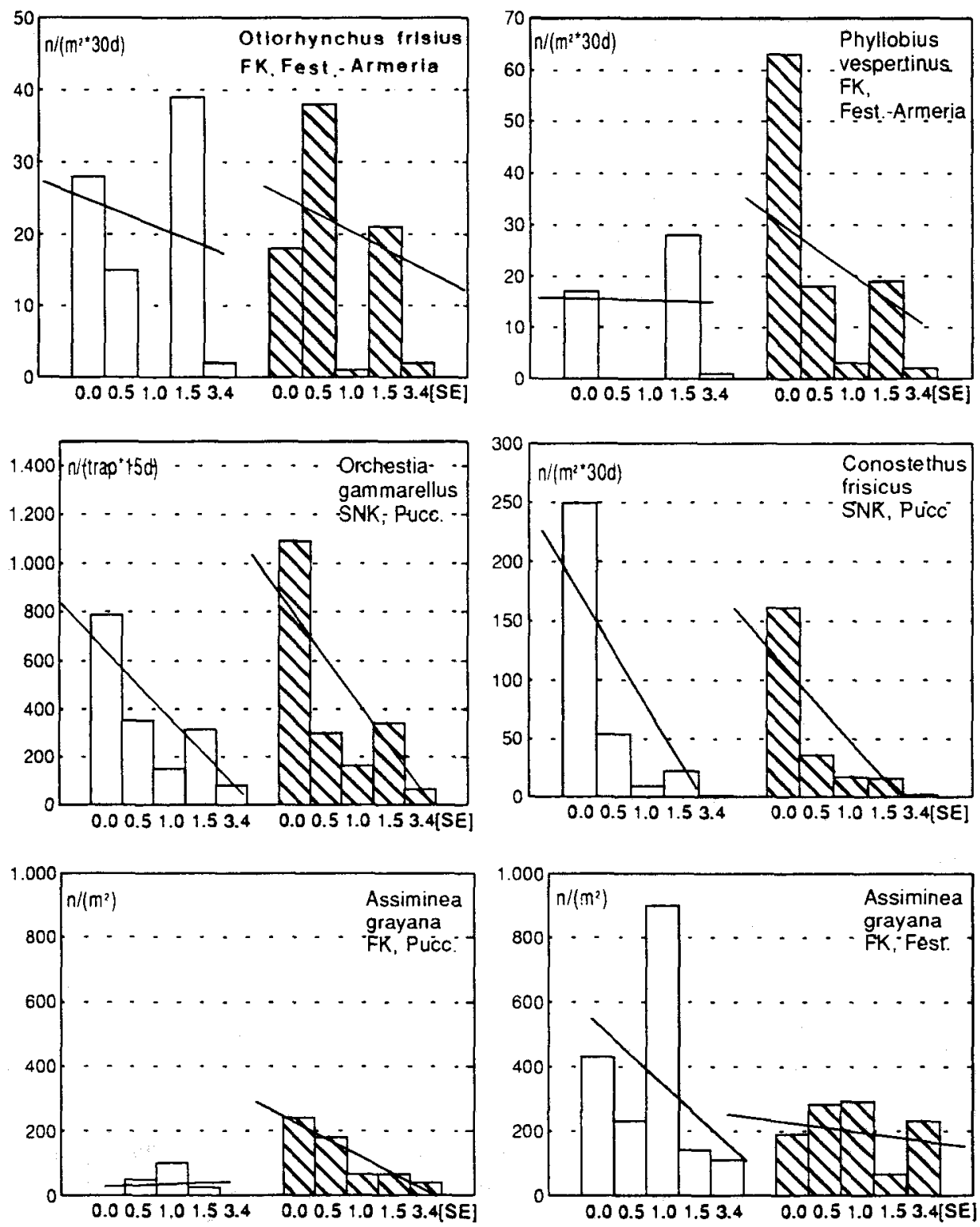

Fig. 5. Species of low grazing endurance. 1990 curves (white columns on the left) and 1991 curves (shaded columns on the right) show average seasonal values. Abscissa: Grazing intensities in sheep units per ha (SE). Ordinate: Data from photoeclector samples have the unit of measure: density per $\mathrm{m}^{2}$ captured during a period of 30 days, whereas pitfal traps record density captured during a period of 15 days. Regression line depicts the trend of grazing impact. Friedrichskoog (FK), Sönke-NissenKoog (SNK) represent investigation areas. Fest.-Armeria = Festuca-Armeria-zone; Fest. = both Festuca-Armeria- and Festuca-Puccinellia-zone $;$ Pucc. = Puccinellia maritima-zone 

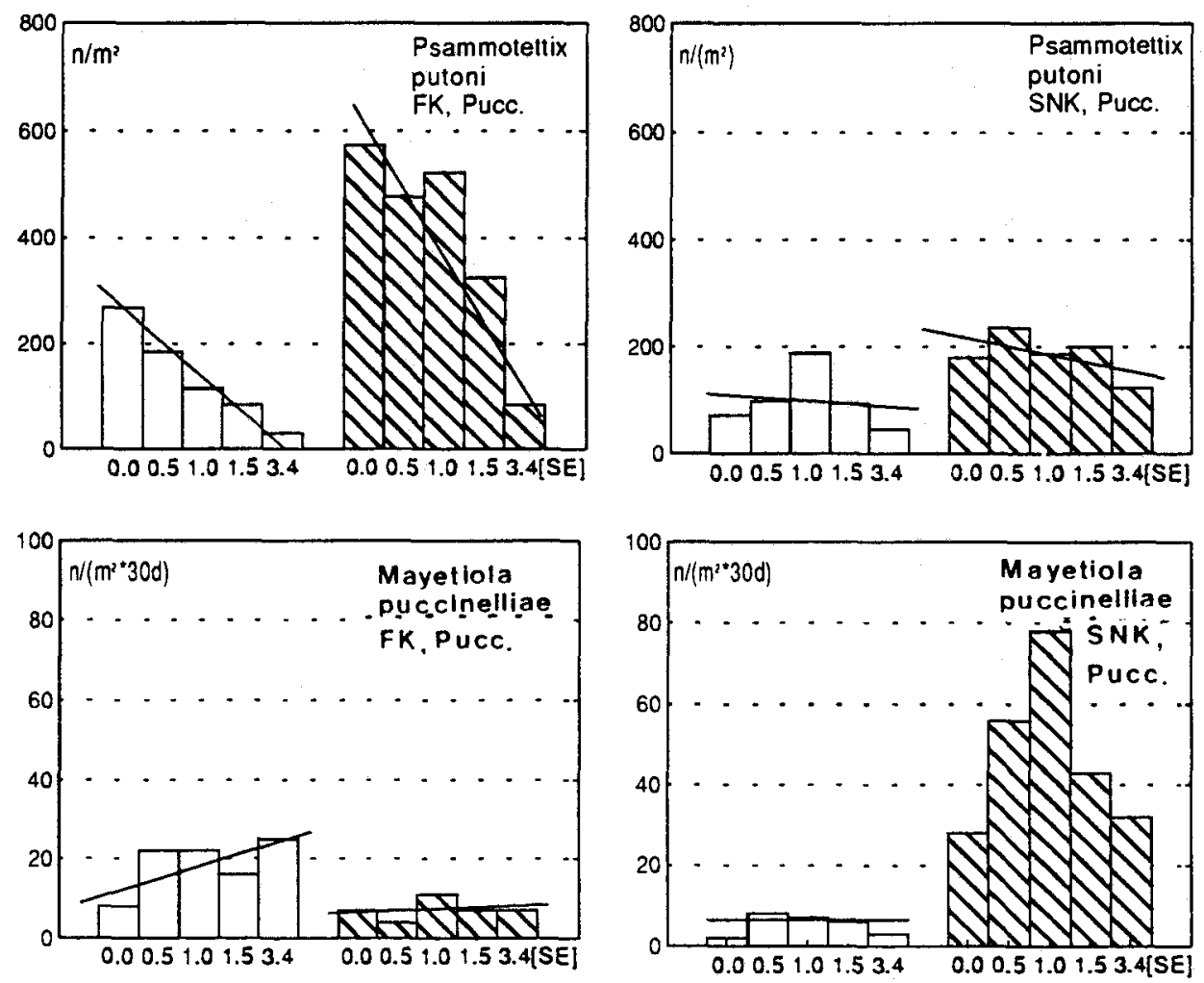

Fig. 6. Species benefiting from enhanced production of fresh plant shoots at medium grazing intensities in Friedrichskoog (FK) and Sönke-Nissen-Koog (SNK) 1990-1991. For explanation of abbreviations, see legend of Fig. 5

low values in comparison to the FK area with an overall average (including all zones) of $22400 \mathrm{n} / \mathrm{m}^{2}$ at that time (October 1990) with $32200 \mathrm{n} / \mathrm{m}^{2}$ with maximal grazing and $12600 \mathrm{n} / \mathrm{m}^{2}$ with zero grazing. The SNK Puccinellia maritima-zone displayed reactions to grazing similar to those observed in the Festuca-zone of FK.

\section{Increase and decrease in predators}

The dolichopodid flies, Micromorphus albipes (Fig. 8) and Syntormon pallipes, preferred the Festuca-Puccinellia-zone habitat (Sommer, 1978; Meyer \& Heydemann, 1990). The trend showed a 'positive' reaction to grazing in 1990, but an indifferent reaction in 1991, favouring the $1.5 \mathrm{SE}$ grazing intensity in both years. Another dolichopodid fly Hydrophorus oceanus, reached its maximum under maximum grazing conditions. This species normally lives in bare soil of the lower salt marsh sites and preys on small arthropods, such as the amphipod Corophium volutator (Mills, 1981). The carabid beetle Dicheirotrichus gustavii took advantage of the grazing (Fig. 8); whereas the carabid beetle Pogonus chalceus (not depicted), decreased in density.

Web-trapping spiders suffered from grazing. The population density of the dwarf spiders Baryphyma duffeyi in SNK and Erigone longipalpis in FK (B. duffeyi not present 

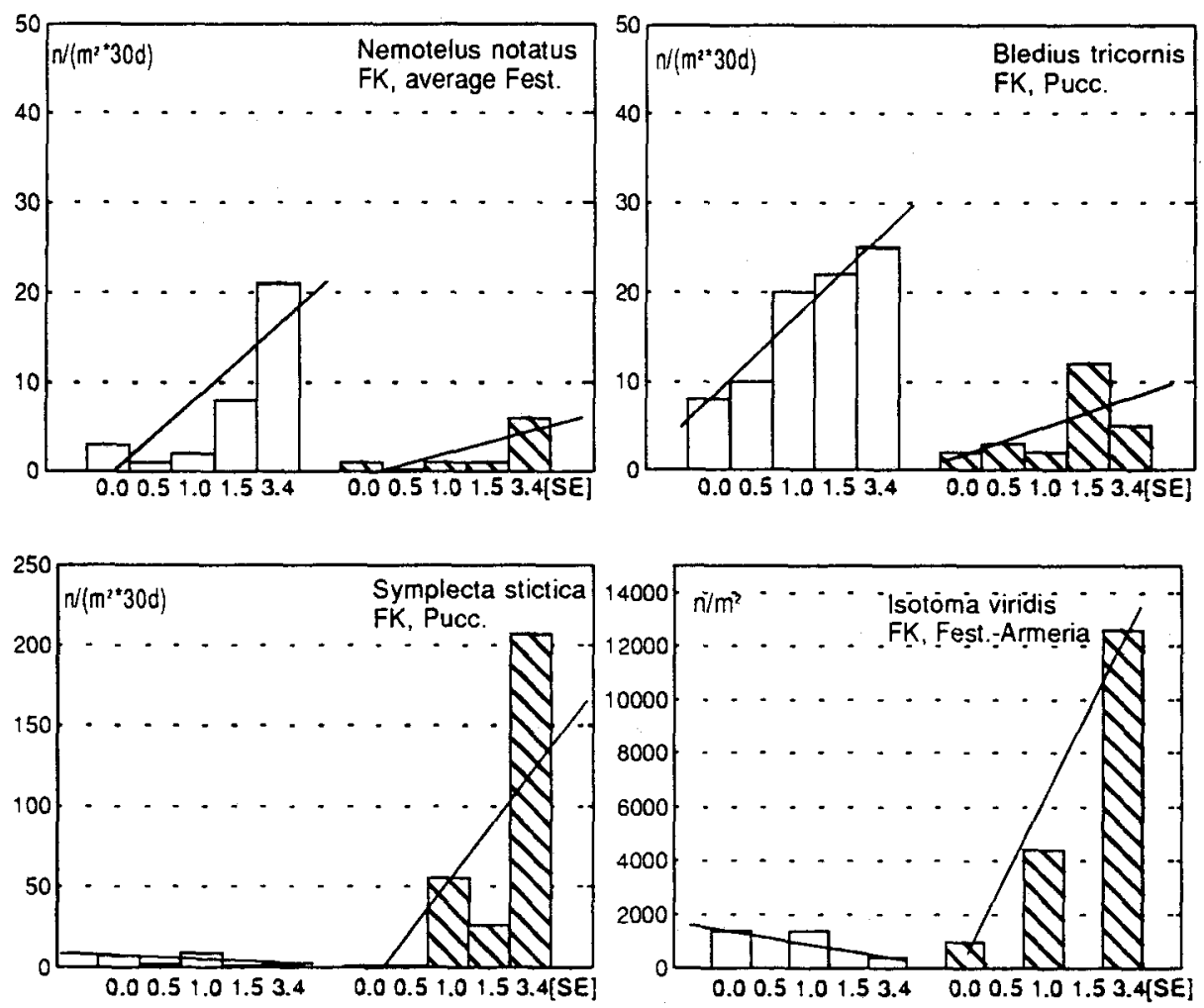

Fig. 7. Increasing abundance of microphotophages and little detritophages in Friedrichskoog (FK) 1990-1991. For explanation of abbreviations, see legend of Fig. 5

in FK), declined consequently with increasing sheep stocking rates. In SNK, however, the density of $E$. longipalpis increased coincidentally with a reduction in the $B$. duffeyi population (Fig. 8). Here E. longipalpis and $B$. duffeyi also showed a corresponding phenology with an autumn maximum for $E$. longipalpis and a spring maximum for $B$. duffeyi (Fig. 9). It appeared that the decreasing populations and phenological gaps of one species were advantageous for the other species. This revealed the probable importance of competition mechanisms for the regulation of population dynamics of predators in salt marshes.

The activity index (specimen per pitfall trap/population density in emergent traps) showed that grazing leads to higher relative activity for the carabid beetle Dicheirotrichus gustavii in 1991 and the dwarf spider Baryphyma duffeyi in 1990/91. This negatively affected the energy budget of the specimen (Fig. 10). Irmler et al. (1987) used data from suction samples instead of emergent traps to derive activity indices with the same results for Erigone longipalpis.

\section{Secondary production and turnover rates of herbivorous invertebrates}

The secondary production per generation of Psammotettix putoni, a cicad, yielded highest values in the ungrazed fields of FK with an enormous production of the spring 

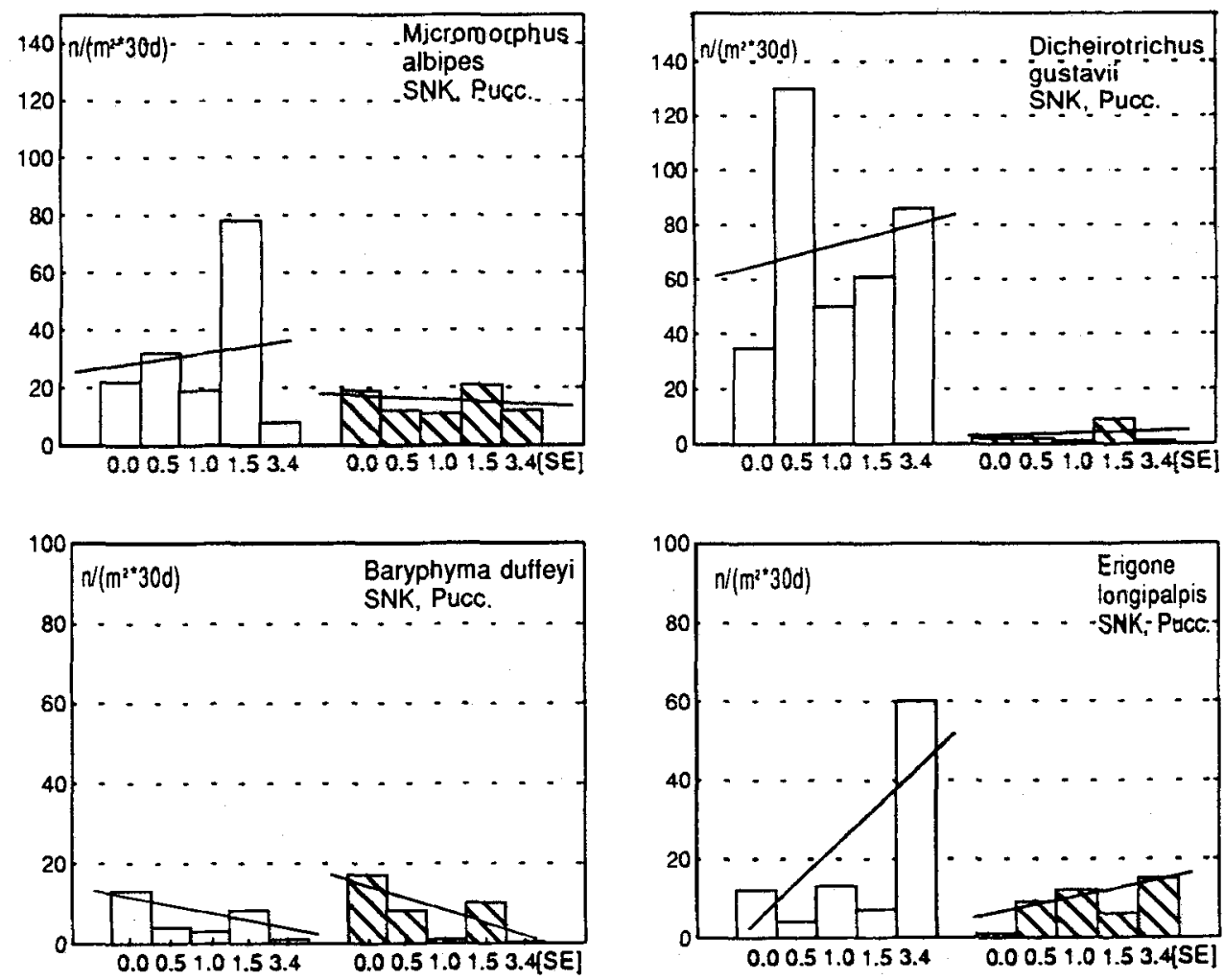

Fig. 8. Increasing and decreasing abundance for predators in Sönke-Nissen-Koog (SNK) 1990-1991. The population sizes decreased in 1991, except in Baryphyma duffeyi. For explanation of abbreviations, see legend of Fig. 5

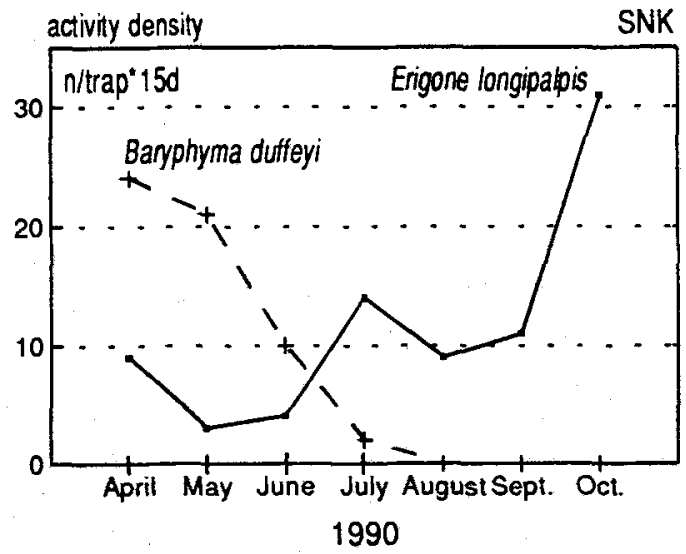

Fig. 9. Phenology of Baryphyma duffeyi and Erigone longipalpis in the Puccinellia maritima-zone of Sönke-Nissen-Koog (SNK) 1990 with an average of 25 sampling sites. Ordinate: Data from pitfall traps recorded as activity density per trap and 30 days. Grazing influence is omitted from the graph 

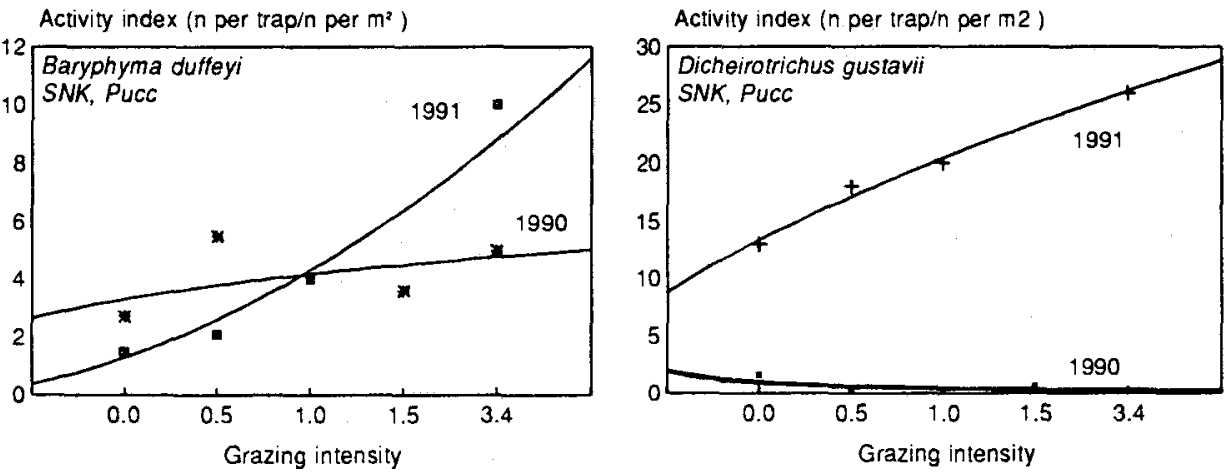

Fig. 10. Activity index for Dicheirotrichus gustavii and Baryphyma duffeyi in the Puccinellia maritima-zone of Sönke-Nissen-Koog (SNK) 1990-1991. One dataset omitted in each case. Ordinate: Data from pitfall traps ( $\mathrm{n}$ per trap) in relation to data from photoeclector samples ( $\mathrm{n}$ per $\mathrm{m}^{2}$ )

generation in 1991 (Fig. 11, right). This exceptional feature of a booming spring generation followed by a breakdown in the second generation also occurred in the ungrazed sites in SNK, as well as in the moderately grazed sites in FK in 1991. In all other cases, the second generation yielded higher values, when compared to the spring generation. In FK, all-seasons production decreased with increasing grazing intensity, which revealed the influence of geese-grazing (Fig. 6). In SNK, the moderately grazed fields had the highest all-season production in 1990 and 1991. High values of secondary production indicate good living conditions with respect to the food availability and quality, and microclimate.

The plantbug Conostethus frisicus (Table 4), having a higher longevity, exhibited slightly lower average values for the turnover rate (P/B-ratio), when compared to the short living cicad $P$, putoni. Both species showed significant grazing response, especially in the totally grazed fields.
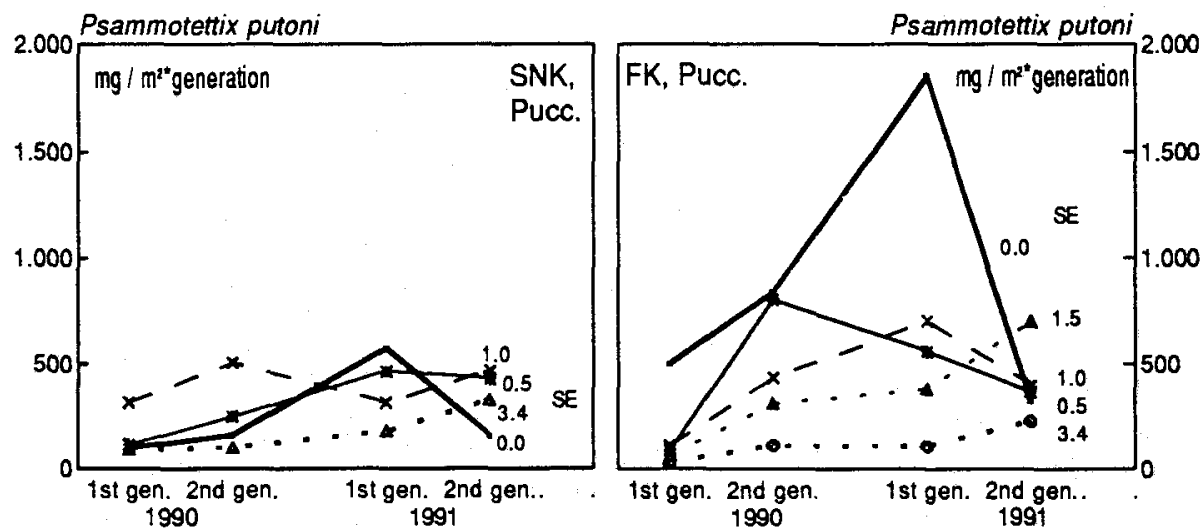

Fig. 11. Production per generation of Psammotettix putoni in the Puccinellia maritima-zone of Friedrichskoog (FK) and Sönke-Nissen-Koog (SNK) 1990-1991 
Table 4. Turnover rates $(\mathrm{P} / \mathrm{B}=$ production/biomass) in Sönke-Nissen-Koog (SNK) 1991. $\mathrm{SE}=$ grazing intensity in sheep units per ha

\begin{tabular}{|ccc|}
\hline $\begin{array}{c}\text { Grazing intensity } \\
\text { (SE) }\end{array}$ & $\begin{array}{c}\text { Turnover rates (P/B) } \\
\text { Conostethus frisicus }\end{array}$ & $\begin{array}{c}\text { in SNK for } \\
\text { Psammotettix putoni }\end{array}$ \\
\hline 0.0 & 2.95 & 3.90 \\
0.5 & 3.27 & 2.90 \\
1.0 & 4.57 & 4.15 \\
1.5 & 3.53 & 3.75 \\
3.4 & - & 4.10 \\
\hline
\end{tabular}

\section{Size distribution of Assiminea grayana}

The size distribution of the population of the gastropod Assiminea grayana is obviously affected by sheep-grazing (Fig. 12, late summer in 1991). Although more distinct in the FK area, a general pattern seemed to emerge, revealing relatively few, small and many large specimen in the ungrazed to lightly grazed sites, but a different size composition under medium to intensively grazed conditions. In both of the salt marsh areas, two main size groups could be distinguished: juvenile snails with a mean shell

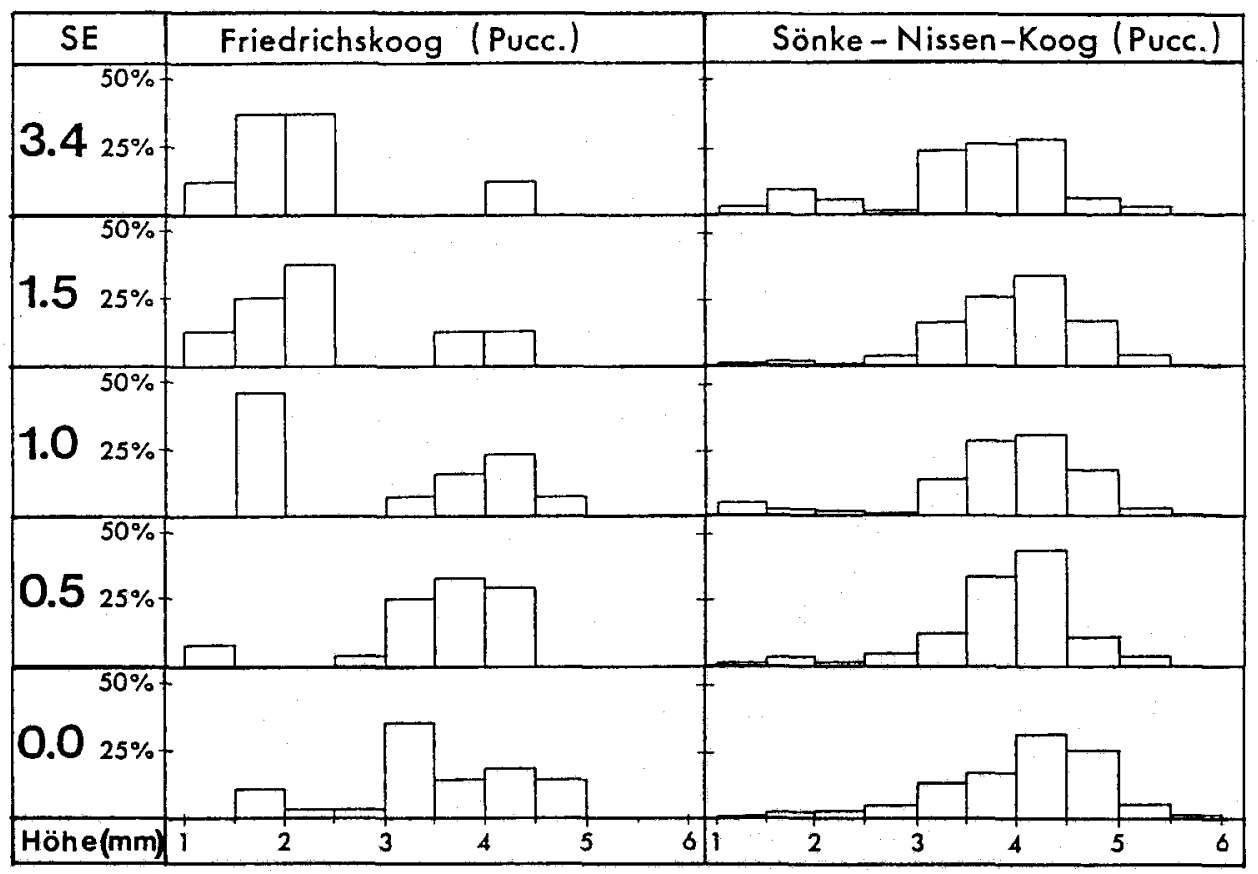

Fig. 12. Size-frequency distributions of Assiminea grayana in the Puccinellia maritima-zone of Friedrichskoog (FK) and Sönke-Nissen-Koog (SNK) in late summer 1991. Abscissa: Shell length in 
length of ca $1.7 \mathrm{~mm}$, and a parental generation with ca $4 \mathrm{~mm}$ in mean length. In the FK area the number of the latter amounted to ca $10 \%$ when grazing pressure was most intensive, but reached ca $75 \%$ when sheep were absent. Moreover, the population of $A$. grayana showed a greater variance in size classes with decreasing stocking rates.

\section{Effects on community level}

\section{Dominance structure}

The invertebrate community of the investigated salt marsh areas was characterized by the numerical dominance of only a few species (Table 5). In 1990/91 23 species contributed $80 \%$ of the total abundance in the Festuca-zone (FK). In the Puccinellia maritima-zone, 19 and 17 species out of more than 250 species in total made up the same amount of total abundance in the FK and SNK, respectively.

Within each marsh type, hardly any difference in the species diversity occurred. In 1990, a total of 42 species was recorded in the high salt marsh of FK, as well as in both low marsh sites. Comparisons between grazing intensities also revealed no difference in species number.

\section{Biomass patterns}

Grazing did not affect the soil properties in the low-lying salt marsh (FK, Pucc.). Hence, the effect of grazing on the animal community could be observed here directly (Fig. 5; gastropod: Assiminea grayana, amphipod: Orchestia gammarellus). The biomass and abundance of the total collembolan population decreased in a clear trend subsequent to grazing intensity (Fig. 13). This trend was the same for the biomass of Assiminea grayana (Fig. 13).

The biomass data of photoeclector samples, which was comprised of 62 species, created a more heterogenous picture, but still with a clear trend (Fig. 14). The involved taxa were (a) Coleoptera (Chrysomelidae, Curculionidae), (b) Rhynchota (Cicadina, Miridae), and (c) Diptera (Cecidomyiidae, Limoniidae, Agromyzidae, Dolichopodidae, Empididae, Hybotidae, Lonchopteridae, and Stratiomyiidae). Generally, herbivores responded negatively, especially to total grazing. The $1.5 \mathrm{SE}$-intensity showed a considerable peak which was only detectable for herbivores. Detritophages benefited clearly from grazing. Predators from FK, for both the Festuca- and Puccinella-zones, showed a slightly declining trend, whereas predators from SNK-sites benefited from grazing.

The resulting curves for the Festuca-zone of FK show a considerable congruency with those of the Puccinellia-zone of SNK, except for predators.

Among the selected group of invertebrates (Fig. 14), phytophages, with an overall average of $41 \mathrm{mg} \mathrm{DW} / \mathrm{m}^{2}$ (1990/91, SNK) and $35 \mathrm{mg} \mathrm{DW} / \mathrm{m}^{2}$ (FK, all sites), contributed the major part to the biomass of the emergent fauna, when compared to detritophages (12 mg SNK/21 mg FK) and predators (20 mg SNK/15 mg FK). However, emergent fauna only contributed a small part to the total amount of invertebrate animal biomass, when compared to the collembolan fauna with an average of $52 \mathrm{mg} \mathrm{AFDW} / \mathrm{m}^{2}$ (SNK, October 1990), and to the gastropod Assiminea grayana with an overall average of a remarkable $5080 \mathrm{mg}$ DW/m² (SNK, September 1991).

In FK, Assiminea grayana only yielded on average $655 \mathrm{mg} \mathrm{DW} / \mathrm{m}^{2}$ (1991), whereas the biomass of collembolans increased to an overall average (all zones) of $171 \mathrm{mg}$ AFDW/ $\mathrm{m}^{2}$ (1990/91, June-August). 


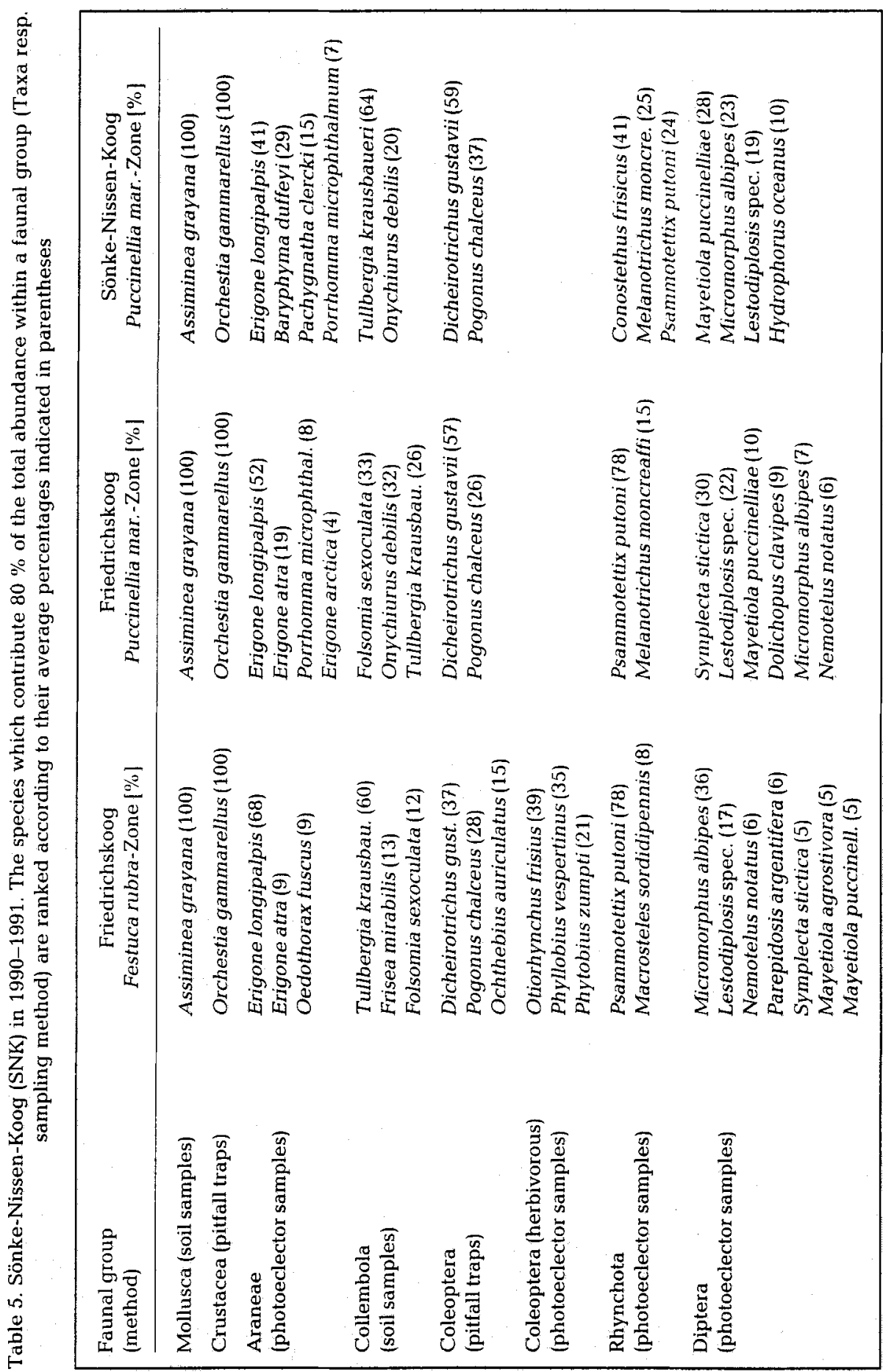



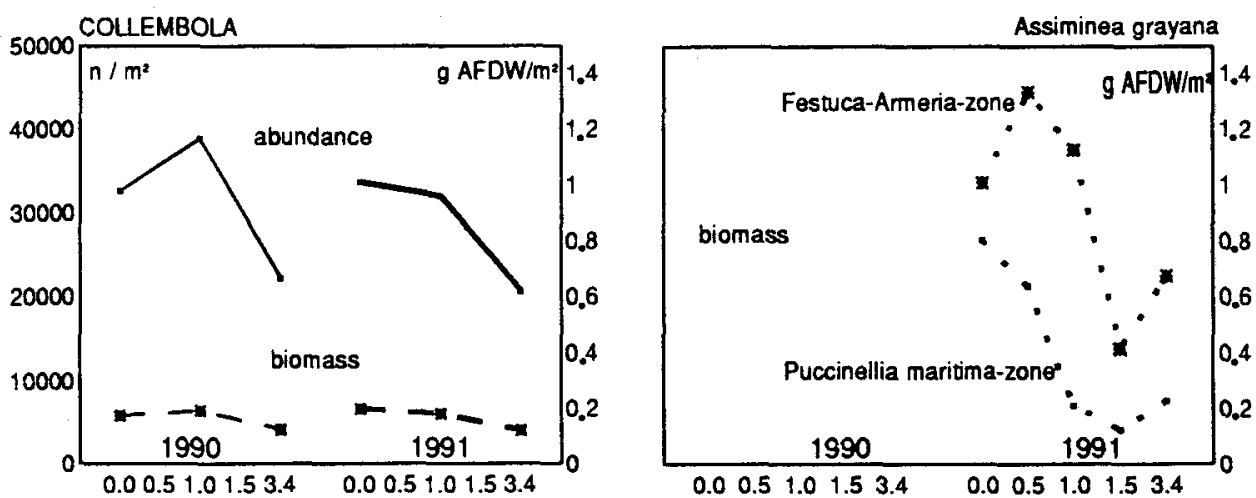

Fig. 13. Biomass-abundance diagram for the collembolan fauna in the Puccinellia maritima-zone of Friedrichskoog (FK) (left), and biomass distribution for Assiminea grayana in the Puccinellia maritima- and Festuca-Armeria-zones in Friedrichskoog (FK) 1990-1991 (right). Abscissa: grazing intensity in sheep-units (SE) per ha

\section{Cluster analysis: patterns of similarity between different salt marsh communities}

The degree of diversity of community structures decreased with increasing grazing pressure; hence, the faunal composition was severely affected by grazing. Within each investigation area, especially in $F K$, the community structure of the first ungrazed marsh near the sea-dike was most dissimilar in comparison to all others (Fig. 15, SNK). In SNK, similarity in the ungrazed first field followed the elevation gradient reflecting the topographic conditions: Seaward sites have a higher elevation level than the trapping points near the seadike, and therefore, were more similar to the first ungrazed field. Dissimilarity increased with both sinking elevation level and increasing grazing pressure. Actually, in 1990, the middle fields, which have the highest elevation level, formed a close group related to field one. In 1991, the abandoned sites formed one group, followed again by a group located in the middle fields. The obvious congruence between the 1.5 SE sites with both the $0.5 \mathrm{SE}$ and $0.0 \mathrm{SE}$ sites was probably due to the neighbouring effects of these adjacent sites. The level of differentiation (range of distance between individual cluster) decreased from 1990 to 1991. The last cumulative cluster in 1991 already joined at the $55 \%$-level compared to $32 \%$ in 1990. In 1991 the ungrazed sites only belonged to one group.

In $\mathrm{FK}$, the elevation patterns were in the same order as the sampling points, so that the resulting figure showed a similarity arranged gradually apart from the first ungrazed field. This confirmed the results of Irmler \& Heydemann (1986) in the Ley-Bight of Lower Saxony.

\section{Interannual changes 1990-1991}

From 1990 to 1991, besides decreasing cummunity differentiation, many species showed remarkable changes in abundance. The predators Erigone longipalpis (Araneae), Dicheirotrichus gustavii (Carabidae), Pogonus chalceus (Carabidae), Micro- 

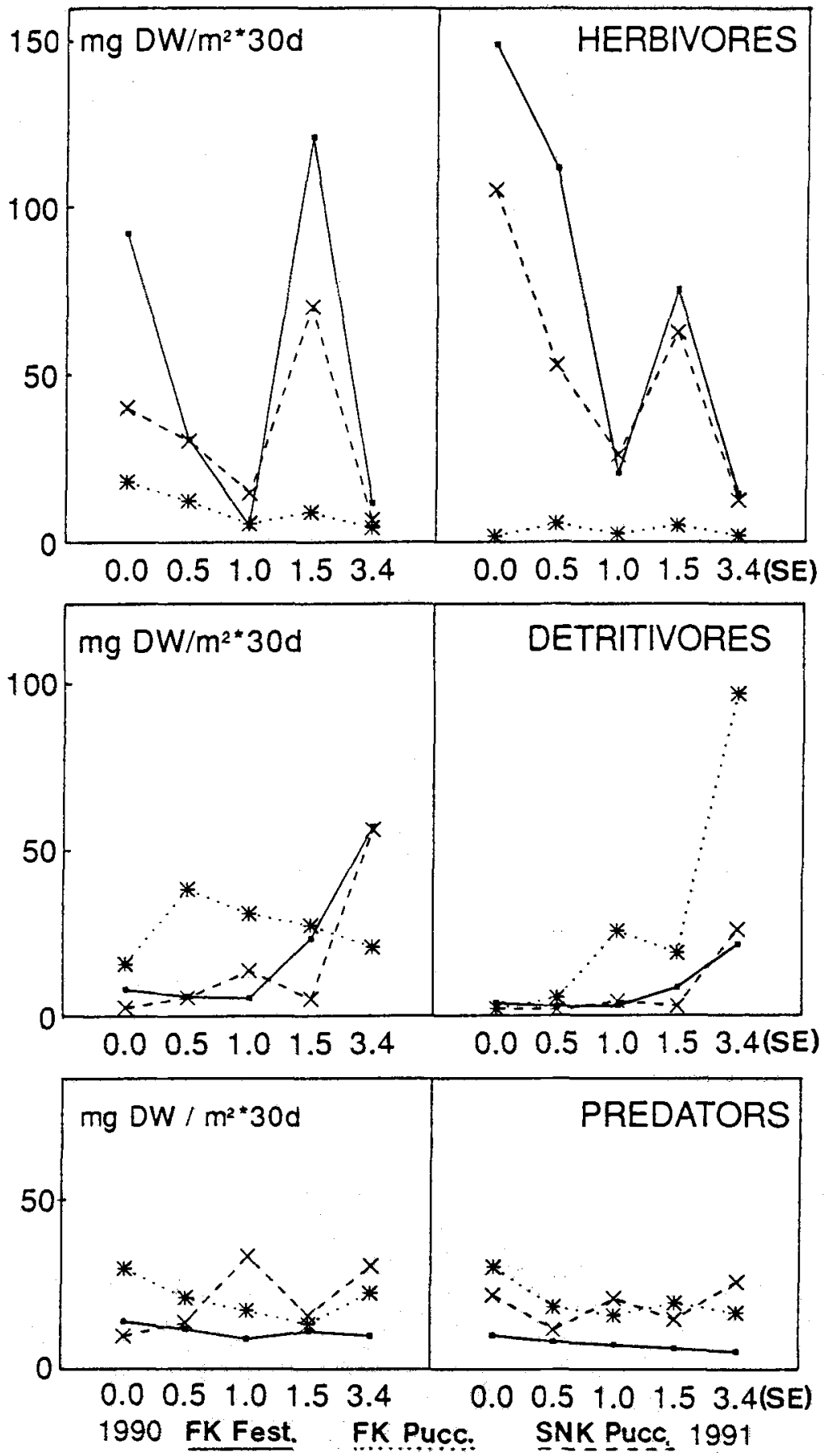


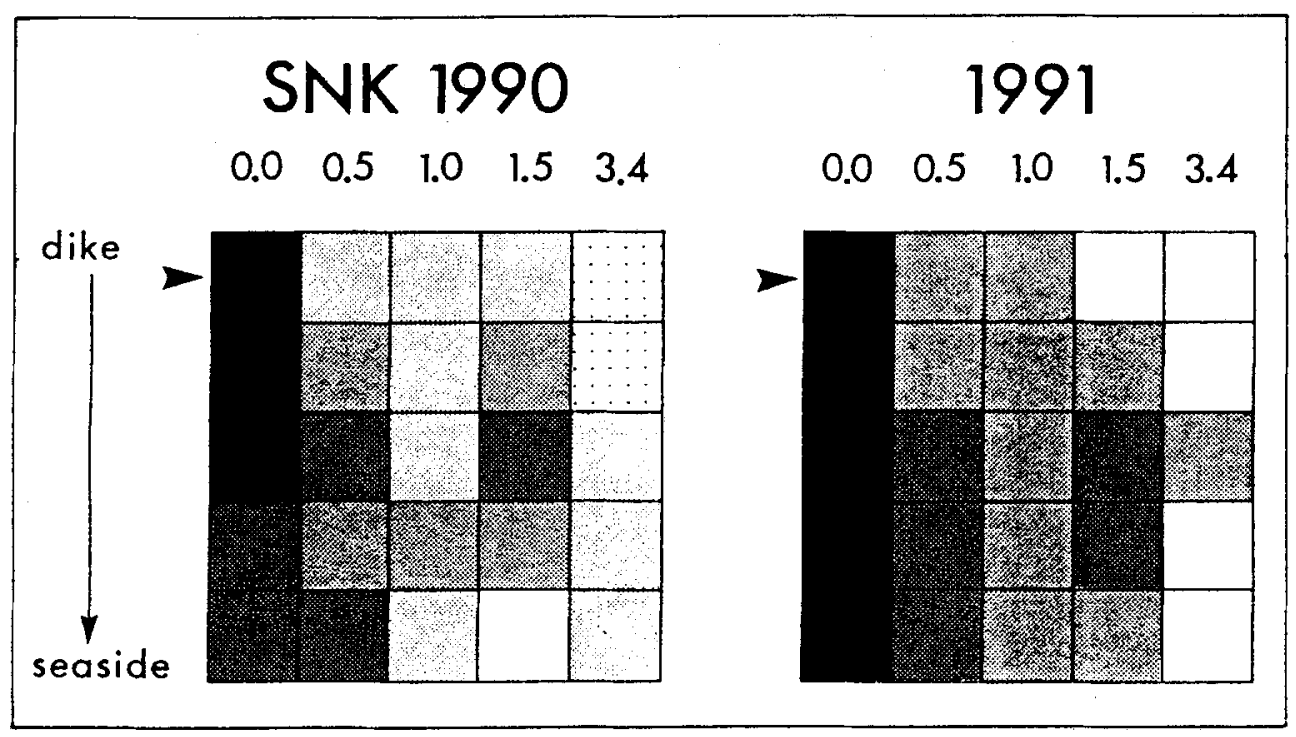

Fig. 15. Summary of the Renkonen index cluster analysis results for pitfall traps in Sönke-NissenKoog 1990-1991 depicted as the degree of relationship to the first ungrazed field ( $\rightarrow$ arrow). Classes represent cumulative cluster incorporating the first ungrazed field. Similarity classes compared to field one are (1990, descending, \%): 97.1 (black), 92.8, 88.3, 70.9, 54.3, 32 (white); respectively for 1991: 96.8 (black), 87, 72, 55 (white)

morphus albipes and Syntormon pallipes (Dolichopodidae) diminished in abundance. Bledius tricornis (Staphylinidae), Conostethus frisicus (Miridae) and Nemotelus notatus (Stratiomyiidae) reacted similarly.

Increasing densities have to be mentioned for many phytophages and detritrophages, e.g. Phyllobius vespertinus (Curculionidae), Anoscopus limicola and Psammotettix putoni (Cicadina), Melanotrichus moncreaffi (Miridae), Symplecta stictica (Limoniidae), Mayetiola agrostivora and Mayetiola puccinelliae (Cecidomyiidae) and collembolans. For collembolans, the distribution pattern changed significantly. In 1990, the Puccinellia maritima-zone was preferred (FK), whereas in 1991, the whole system, at a higher level, shifted to the totally grazed Festuca-Armeria-zone (Figs $16 \mathrm{~A}, \mathrm{~B}$ ). Phasephase-plots of soil humidity (average water content in saturation-\% related to field capacity) and of collembolan biomass demonstrated the importance of the moisture factor (Figs $16 \mathrm{C}, \mathrm{D}$ ). The sites with low humidity showed relatively higher population densities. In 1991, soil humidity decreased, while population density underwent a considerable

Fig. 14. Biomass of 64 selected species from photoeclector samples in the Festuca rubra-zone Friedrichskoog (FK Fest.) and in the Puccinellia maritima-zones of Friedrichskoog (FK Pucc) and Sönke-Nissen-Koog (SNK Pucc), depicted for the trophic groups of herbivores, detritophages, and predators. Abscissa: grazing intensity in sheep-units (SE). For graphic reasons a line graph was chosen 
increase. The Festuca-sites were the most undersaturated at the 3.4-SE level in 1990 and 1991 and in both years, these sites had exhibited relatively high biomass levels (Figs 16 C, D). Contrastingly, the Puccinellia-stands are the most undersaturated under zero grazing, which resulted in relatively high biomass values.
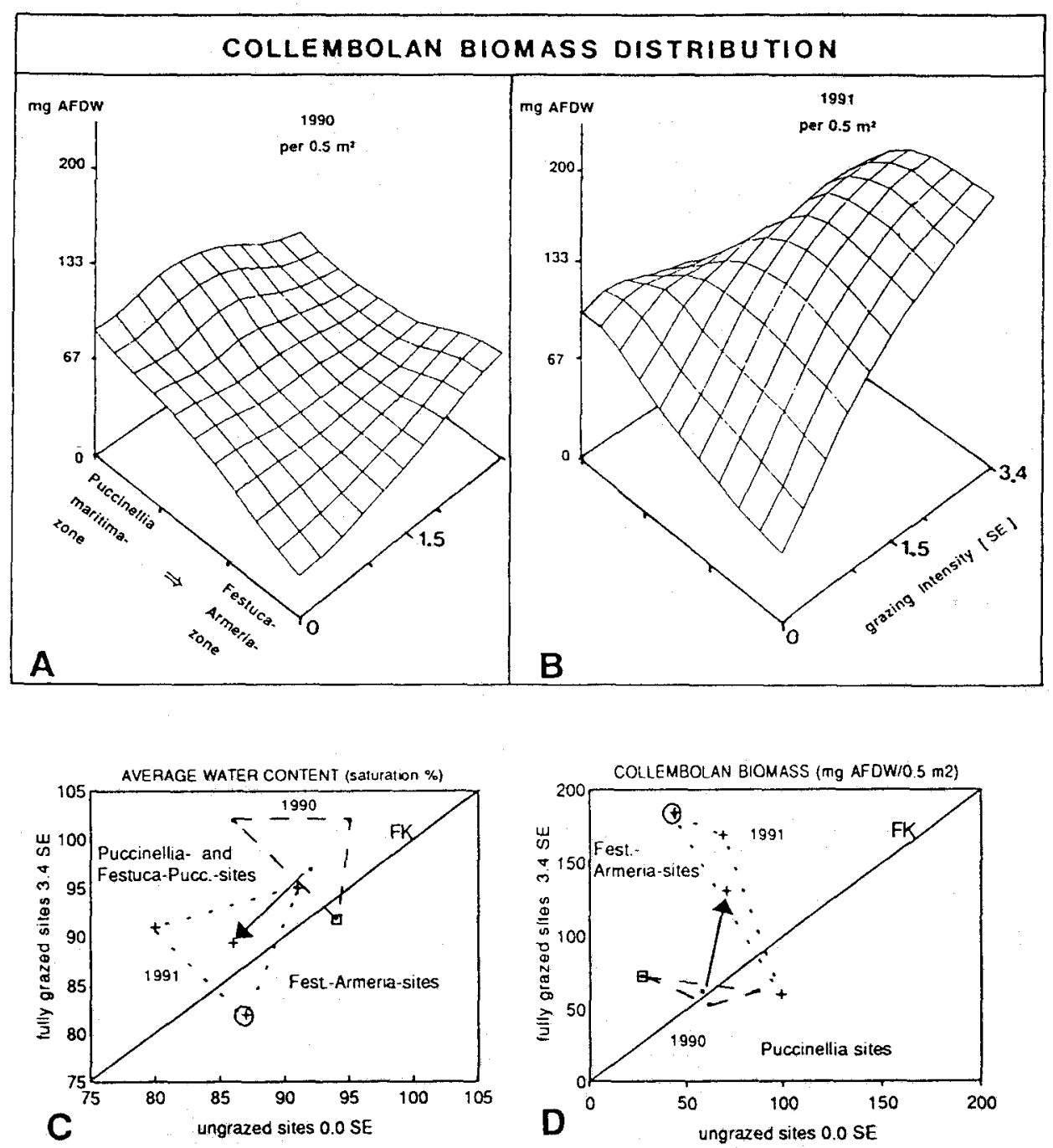

Fig. 16 A, B: Biomass distribution in different salt-marsh zones of Friedrichskoog (FK) for the collembolan fauna for 1990 and 1991. C, D: Phase-phase-plots of the ungrazed vs. totally grazed sites for biomass and soil humidity showing a vice-versa reaction. $\square$ 1990; $\bigcirc 1991$ 


\section{DISCUSSION}

Grazing changed the biotic and abiotic environment of the salt marsh ecosystem. Population densities and species composition of the faunal communities were severely affected.

\section{Environmental conditions}

Irmler \& Heydemann (1986) and Svendsen \& Blicher-Mathiesen (1992) pointed out that trampling by cattle and horses leads to higher bulk density. However, this study showed that sheep introduce a quite different effect to the upper soil environment, lightening the grazed ground via enhanced growth of roots, leaving behind a flat 'golf lane'. Rahmann et al. (1987) reported a concentration of root biomass in the upper soil layer, although the total amount of root-biomass was reduced by half. In fact this is contrary to the uprooting effect caused by cattle and horse grazing on soft muddy ground. Besides effects such as defoliation, removal of nutrients, deposition of excrements, and grazing patterns, uprooting also has a major influence on the soil system (Jensen et al., 1990). In this study, both areas were frequently covered by evenly dispersed excrements and detrital material over all investigation fields. The higher amount of organic material in the ground in the 3.4 SE Festuca-sites might have been due to the reduced decomposition capacity under higher salinity conditions. The importance of very high salinity in limiting decomposition has been mentioned by Hemminga et al. (1991). The ungrazed sites have the most decaying material on the ground which builds up a tomentous layer creating a special habitat for itself to be deteriorated by grazing (e.g. Orchestia gammarellus-Amphipoda). Moreover, the vegetation acts as a climatic buffer for the soil environment.

The difference in soil texture between FK (finesand) and the clayish SNK could explain the low density of collembolans on the SNK-sites with probably lower pore volume. A higher amount of nutrients due to reduced leaching at the clayish sites could provide better conditions for soil algae, resulting in higher densities of grazers such as Assiminea grayana (Gastropoda).

\section{Grazing effects}

Mainly herbivorous species were affected negatively by grazing (e.g. Assiminea grayana-Gastropoda, Otiorhynchus frisius-Curculionidae, Anoscopus limicola-Cicadina, Conostethus frisicus-Miridae, flower visitors and inhabitants such as Paroxyna plantaginis-Tephritidae). Defoliation, decline of grazing-sensitive host plant stands, reduction of special food resources like pollen and nectar, and habitat deterioration by trampling are the main reasons. A minor part of the herbivorous fauna profits from enhanced plant growth on moderately grazed fields, which is a compensatory mechanism for the vegetation to cope with grazing pressure (Psammotettix putoni-Cicadina, Mayetiola puccinelliae-Cecidomyiidae). Compensatory growth under moderate utilization resulting in even higher amounts of available resources has been described for many systems (McNaugthon, 1983; Richter, 1985). This could be one reason for the peak recorded at the 1.5 SE-intensity for many species, but other factors like predation by birds may also play an important role. The observed shift within the size distribution of the gastropod 
Assiminea grayana from small to larger individuals under grazing pressure (Fig. 12) could be an effect of foraging by birds. Reise (1985) reports that birds preferably prey on the larger soil fauna of the tidal flats, which causes enhanced survival of small-sized specimen. Because grazing by sheep leads to a reduction of the vegetation cover, birds in turn would be able to forage more intensively and unhampered on A. grayana.

Large soil-living species with little dwelling ability, such as curculionid larvae and the amphipod Orchestia gammarellus, suffer from intense penetration of the soil by roots, especially at the 3.4 SE-intensity. Whereas typical soil-dwellers such as the microphytophagous Bledius tricornis (Staphylinidae) benefit from grazing, due to higher amounts of bare soil warmed by the solar radiation together with a probable increase of food resources (e.g. soil algae). Increasing food resources support population development for Symplecta stictica (Limoniidae) and also Nemotelus notatus (Stratiomyidae).

Andresen et al. (1990) demonstrated in their cattle-grazing study report that grazing changes community structure from dominance of herbivores to dominance of detritivores. The same is true here, except for collembolans, which do not react the same way under cattle grazing as they do under sheep grazing. In this study they increased in biomass towards the intensively grazed Festuca-sites, whereas they were extremely diminished in number through grazing according to Andresen et al. (1990). In that study, a suction sampler with high efficiency only for epigaeic species was used, while a Kempsonextraction was used in this study with high efficiency for endofauna. Nevertheless, cattleand sheep-grazing appear to affect the fauna in the same way (Andresen et al., 1990; Grell, 1992), although they influence the abiotic environment differently.

\section{Similarity patterns and zonation}

Jensen et al. (1990) reported that grazing animals first choose the moist lower parts of the salt marsh. So there must be a high similarity between intensively grazed zones and moderately grazed low marsh zones. This was verified by Irmler \& Heydemann (1986) and also by this study.

Although cluster analysis showed little affinity between the two investigation areas SNK and FK, there are certain congruencies of ecological reaction between the Festucazone of FK and the Puccinellia-zone of SNK, concerning the distribution of collembolans (Fig. 13), the gastropod Assiminea grayana (Fig. 5), and the emergence of phytophages and detritophages (Fig. 14) from these sites.

Both zones (Festucetum FK, Puccinellietum SNK) also showed a higher variation of abiotic factors. The Puccinellia maritima-zone of FK exhibited no evident variation in abiotic factors related to grazing, and the fauna reacted ecologically differently for the mentioned groups. In conclusion, the degree of shelter (shoreline distance) together with the elevation level, which indicates a certain inundation frequency, and the soil texture seem to play the most important role for the evolution of ecosystem characteristics of salt marshes. 


\section{Descriptive model for interannual changes}

Climatic variation from 1990 to 1991 showed a decrease in the annual mean temperature of about $1.3^{\circ} \mathrm{C}$, mainly due to severe winter temperatures in February 1991, and a reduction of $25 \%$ for precipitation.

Precipitation influences soil humidity. Inundation is omitted from the model, since the situation is assumed to be the same for both years. Soil humidity does not affect decomposition in salt marshes, because water supply usually does not decrease beyond the drought threshold (Hemminga \& Buth, 1991; Hemminga et al, 1991). But with decreasing soil humidity, the volume of air-filled pores in the soil increases with a subsequent increase of soil endofauna, such as collembolans in 1991. Severe winter temperature could hamper the development of species with active overwintering stages (Bledius tricornis-Staphylinidae, several carabids, spiders). Inactive winter stages (e.g. eggs of cicads, pupae of curculionids) and late spring developers (Symplecta sticticaLimoniidae) are less affected. So the reduction of mainly predators leads to a considerable increase of abundance in the potential prey species. Secondly, the cold period in February 1991 combined with the cold spring of 1991 postponed both the beginning of plant growth and the population development of Psammotettix putoni. Besides sufficiently developed host plant stands, the temperature course in April represents the main triggering factor due to the nymphal development of $P_{\text {sammotettix. In summer, vegeta- }}$ tion has to cope with salinity stress which leads to reduced productivity, so that high summer temperatures together with little precipitation produce negative effects.

The interannual changes can be explained by: (1) reduction of predators due to a winter breakdown of population size, (2) delay effects due to low temperatures, and (3) reduced soil humidity due to decreased precipitation, which increases habitat space for

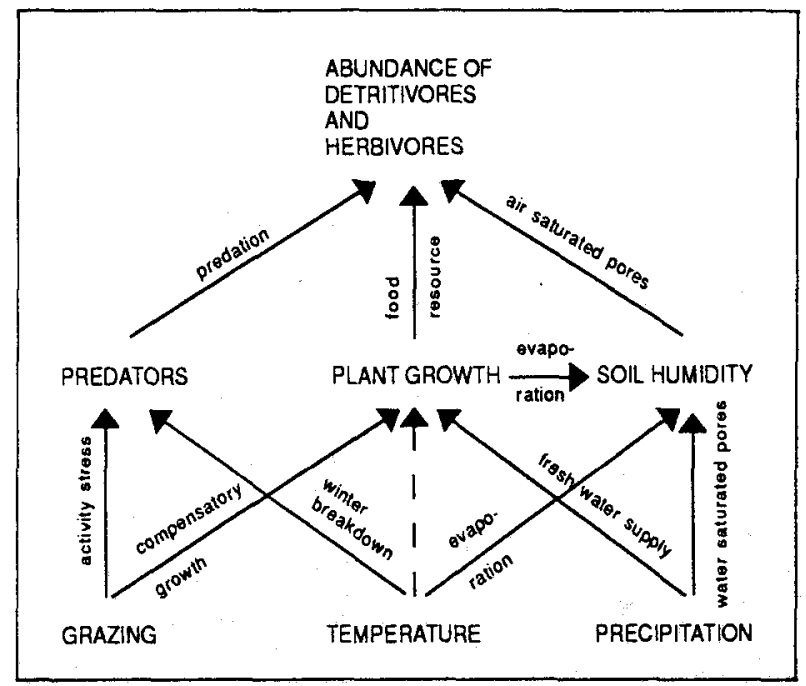

Fig. 17. Descriptive model of the interannual changes 1990 to 1991. Low winter temperatures decrease population size of predators with a resulting increase in prey species density. Reduced precipitation enlarge the volume of air-filled pores in the ground, due to reduced soil humidity, with positive effects on soil endofauna, such as collembolans and dipteran larvae 
soil endofauna (Fig. 17). The fourth factor, grazing, did not change from 1990 to 1991, but it affects soil humidity, predators, and plant growth. For the intertidal reaches, wintergoverned changes of the fauna are well known (Beukema, 1992).

\section{RECOMMENDATIONS FOR MONITORING AND MANAGEMENT}

The dynamics of the ecosystem and the diversity of interactions require a multispecies approach to biological-effect monitoring of salt marshes. According to the results of this study, all effects caused by grazing and climate variation can be reflected by investigation of the species comprising $80 \%$ of number and biomass of the invertebrate fauna (Table 5). We suggest that this is an appropriate approach for all monitoring purposes. Different soil textures, the degree of exposition and the different vegetation types have to be taken into consideration.

Proposals for management include the reduction of grazing to zero grazing, in order to shift the faunistic dominance spectrum towards the herbivores, which is the natural state for ungrazed salt marshes. Nevertheless, the long-term succession on ungrazed and natural salt marshes leads to a state with those plants dominating that are very rare or not yet present in the investigation area of this study. Jensen (1985) reports a dominance of the dwarf shrub Halimione portulacoides after 35 years of cessation of grazing on low salt marshes. Management concepts should provide conditions to start a long-term succession on a considerable part of the mainland salt marshes.

Acknowledgements. This study is supported by the Federal Environmental Agency, Environmental Research Plan of the Minister for the Environment, Nature Conservation and Nuclear Safety of the Federal Republic of Germany (Grant 10802 085/21), and by the state of Schleswig-Holstein.

\section{LITERATURE CITED}

Andresen, H., Bakker, J. P., Brongers, M., Heydemann, B \& Irmler, U., 1990. Longterm changes of salt marsh communities by cattle grazing. - Vegetatio 89, 137-148.

Bakker, J. P., 1990. Effects of grazing and hay-making on Wadden Sea saltmarshes. In: Proceedings of the second trilateral working conference on saltmarsh management in the Wadden Sea region. Ed. by C. H. Oversen. Ministry of the Environment, Esbjerg, 51-72.

Beukema, J. J., 1992. Long-term and recent changes in benthic macrofauna. - Publ. Ser. Neth. Inst. Sea Res. 20,135-141.

Brey, T., 1986. Formalin and formaldehyd-depot chemicals: effects on dry weight and ash free dry weight of two marine bivalve species. - Meeresforsch. 31, 52-57.

Grell, O., 1992. Einfluß der Rinderbeweidung auf Brackwasser-Röhricht und Insel-Salzwiese. Faun. ökol. Mitt. (Suppl.) 13, 5-7; 21-43; 85-87.

Hemminga, M. A. \& Buth, G. J. C., 1991. Decomposition in salt marsh ecosystems of the s.-w. Netherlands: the effects of biotic and abiotic factors. - Vegetatio 92, 73-83.

Hemminga, M. A., Leeuw, J. de, Munck, W. de \& Koutstaal, B. P., 1991. Decomposition in estuarine salt marshes: the effect of soil salinity and water content. - Vegetatio 94, 25-33.

Heydemann, B., 1956. Die Bedeutung der Formalinfallen für die ökologische Landesforschung. Faun. Mitt. Norddeut. 6, 19-24.

Heydemann, B. \& Müller-Karch, J., 1981. Wattenmeer, Bedeutung - Gefährdung - Schutz. Deutscher Naturschutzring, Bonn, 49 pp.

Hildebrandt, J., 1990. Terrestrische Tiergemeinschaften der Salzwiesen im Aestuarbereich. Diss., Univ Bremen, $290 \mathrm{pp}$.

Irmler, U. \& Heydemann, B., 1986. Die ökologische Problematik der Beweidung von Salzwiesen an 
der niedersächsischen Küste am Beispiel der Leybucht. - Beih. Naturschutz Landschaftspfl. Niedersachsen $15,1-115$.

Irmler, U, Heydemann, B. \& Wrage, H. A., 1987. Veränderungen der Wirbellosenfauna in Salzwiesen durch Beweidung. In: Salzwiesen: geformt vom Küstenschutz, Landwirtschaft oder Natur? Hrsg. von J. Lamp, N. Kempf \& P. Prokosch. WWF Deutschland, Husum, 243-254.

Jensen, A., 1985. The effect of cattle and sheep grazing on salt-marsh vegetation at Skallingen, Denmark. - Vegetatio 60,37-48.

Jensen, A., Skovhus, K. \& Svendsen, A., 1990. Effects of grazing by domestic animals on saltmarsh vegetation and soils, a mechanistic approach. In: Proceedings of the second trilateral working conference on saltmarsh management in the Wadden Sea region. Ed. by C. H. Ovesen. Ministry of the Environment, Esbjerg, 153-161.

McNaughton, S. J., 1983. Compensatory plant growth as a response to herbivory. - Oikos 40, $329-336$

Meyer, H., 1984. Experimentell-ökologische Untersuchungen an Gallmücken (CecidomyiidaeDiptera) in Salzwiesenbereichen Nordwestdeutschlands. - Faun. ökol. Mitt. (Suppl.) 5, 1-124.

Meyer, H. \& Heydemann, B., 1990. Faunistisch-ökologische Untersuchungen an Dolichopodiden und Empididen (Diptera-Dolichopodidae u. Empididae, Hybotidae) in Küsten- und Binnenlandbiotopen Schleswig-Holsteins. - Faun. ökol. Mitt. 6, 147-172.

Mills, A., 1981. Predaceous behavior of Hydrophorus oceanus (Macq.) (Dipt.-Dolichopodidae). Entomologist's mon. Mag. 116, 147.

Prokosch, P., 1990. German salt marshes - formed by agriculture, coastal protection or nature? In: Proceedings of the second trilateral working conference on saltmarsh management in the Wadden Sea region. Ed. by C. H. Ovesen. Ministry of the Environment, Esbjerg, 35-42.

Prokosch, P. \& Kempf, N., 1987. Die Nutzung der Salzwiesen im schleswig-holsteinischen Wattenmeer. In: Salzwiesen: geformt von Küstenschutz, Landwirtschaft oder Natur? Hrsg. von J. Lamp, N. Kempf \& P. Prokosch. WWF Deutschland, Husum, 101-112.

Rahmann, M., Rahmann, H., Kempf, N., Hoffmann, B. \& Gloger, H., 1987. Auswirkung unterschiedlicher landwirtschaftlicher Nutzung auf die Flora und Fauna der Salzwiesen an der ostfriesischen Wattenmeerküste. - Senckenberg. marit. 19, 163-193.

Reise, K., 1985. Tidal flat ecology. Springer, Berlin, $191 \mathrm{pp}$

Renkonen, O., 1938. Statistisch-ökologische Untersuchungen über die terrestrische Käferwelt der finnischen Bruchmoore. - Annls zool. Soc. zool.-bot. Fennicae van. 6, 1-231.

Richter, O., 1985. Simulation des Verhaltens ökologischer Systeme. VCH, Weinheim, $219 \mathrm{pp}$.

Schott, C., 1956. Die Naturlandschaften Schleswig-Holstein. Wachholtz, Neumünster, 110 pp.

Sneath, P. H. R. \& Sokal, R. R., 1973. Numerical taxonomy. Freemann, San Francisco, 537 pp.

Sommer, R.-G., 1978. Experimentell-ökologische Untersuchungen an Dolichopodiden (Dipt.Dolichopodidae) im Grenzbereich Land/Meer. Diss., Univ. Kiel, 123 pp.

Southwood, T. R. E., 1978. Ecological methods. Chapmann \& Hall, London, 524 pp.

Stock, M., 1993. Salzwiesenschutz in Schleswig-Holstein. - Wattenmeer int. 11 (2), $20-21$.

Svendsen, A. \& Blicher-Mathiesen, G., 1992. The role of trampling on ecophysiological conditions in grazed salt marshes. - Wadden Sea Newsl. 1992 (1), 17-21.

Tischler, T., 1985. Freiland-experimentelle Untersuchungen zur Ökologie und Biologie phytophager Käfer (Coleoptera: Chrysomelidae, Curculionicdae) im Litoral der Nordseeküste. - Faun. ökol. Mitt. (Suppl.) 6, 1-180.

Tulowitzki, I., 1990. Einfluß der Beweidung auf die Populationsstruktur der Kleinzikade Psammotettix putoni (Hom. Auch.) in der Salzwiese der schleswig-holsteinischen Westküste. - Verh. Ges. Ökol. 19 (2), 152-162.

Weigmann, G., 1973. Zur Ökologie der Collembolen und Oribatiden im Grenzbereich Land/Meer (Collembola, Insecta - Oribatei, Acari). - Z. wiss. Zool. 186, 295-391.

Winberg, G. G., Patalas, K., Wright, J. C., Hillbrecht-Ilkowska, A., Cooper, W. E. \& Mann, K. H., 1971. Methods for calculating productivity. In: A manual on methods for the assessment of secondary productivity in fresh waters. Ed. by W. T. Edmondson \& G. G. Winberg. Blackwell, London, 296-303.

Ziegelmeier, E., 1966. Die Schnecken (Gastropoda Prosobranchia) der deutschen Meeresgebiete und der brackigen Küstengewässer. - Helgoländer wiss. Meeresunters. 13, 1-61. 